Consortium for Research on Educational Access, Transitions and Equity

NGO Provision of Basic Education:

Alternative or Complementary

Service Delivery to Support Access to the Excluded?

\author{
Pauline Rose
}

CREATE PATHWAYS TO ACCESS

Research Monograph No 3

June 2007

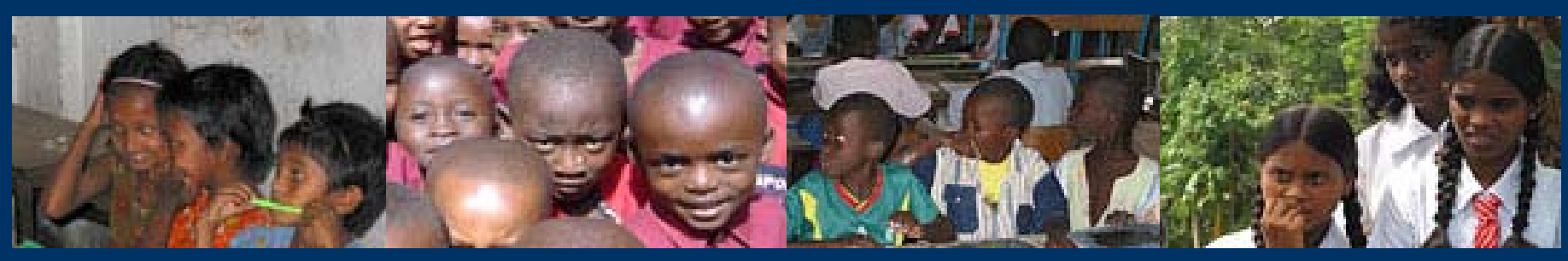

University of Sussex

Centre for International Education 


\section{Crate \\ Consortium for Research on \\ Educational Access, Transitions \& Equity \\ Funded by DFID}

The Consortium for Educational Access, Transitions and Equity (CREATE) is a Research Programme Consortium supported by the UK Department for International Development (DFID). Its purpose is to undertake research designed to improve access to basic education in developing countries. It seeks to achieve this through generating new knowledge and encouraging its application through effective communication and dissemination to national and international development agencies, national governments, education and development professionals, non-government organisations and other interested stakeholders.

Access to basic education lies at the heart of development. Lack of educational access, and securely acquired knowledge and skill, is both a part of the definition of poverty, and a means for its diminution. Sustained access to meaningful learning that has value is critical to long term improvements in productivity, the reduction of inter-generational cycles of poverty, demographic transition, preventive health care, the empowerment of women, and reductions in inequality.

\section{The CREATE partners}

CREATE is developing its research collaboratively with partners in Sub-Saharan Africa and South Asia. The lead partner of CREATE is the Centre for International Education at the University of Sussex. The partners are:

The Centre for International Education, University of Sussex: Professor Keith M Lewin (Director)

The Institute of Education and Development, BRAC University, Dhaka, Bangladesh: Dr Manzoor Ahmed The National University of Educational Planning and Administration, Delhi, India: Professor R Govinda

The Education Policy Unit, University of the Witwatersrand, South Africa: Dr Shireen Motala

The Universities of Education at Winneba and Cape Coast, Ghana: Professor Jerome Djangmah The Institute of Education, University of London: Professor Angela W Little Associate Partner: The Institute of Development Studies at Sussex

\section{Disclaimer}

The research on which this paper is based was commissioned by the Consortium for Research on Educational Access, Transitions and Equity (CREATE http://www.create-rpc.org). CREATE is funded by the UK Department for International Development (DFID) for the benefit of developing countries and is coordinated from the Centre for International Education, University of Sussex. The views expressed are those of the author(s) and not necessarily those of DFID, the University of Sussex, or the CREATE Team.

Copyright (C) CREATE 2007

ISBN: 0-901881-03-1

Address for correspondence:

CREATE,

Centre for International Education, Sussex School of Education,

University of Sussex, Falmer, Brighton BN1 9QQ,

United Kingdom

Tel:

$$
+44(0) 1273678464
$$

Fax:

+ 44 (0) 1273877534

Author Email: p.m.rose@sussex.ac.uk

Website: $\quad$ http://www.create-rpc.org

Email: $\quad$ create@sussex.ac.uk

Please contact CREATE using the details above if you require a hard copy of this publication. 


\title{
NGO Provision of Basic Education: Alternative or Complementary \\ Service Delivery to Support Access to the Excluded?
}

\author{
Pauline Rose
}

CREATE PATHWAYS TO ACCESS

Research Monograph No 3

June 2007 


\section{Contents}

Preface

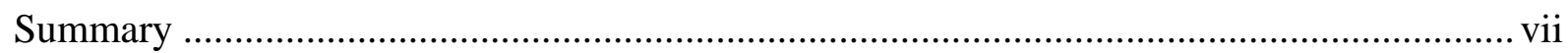

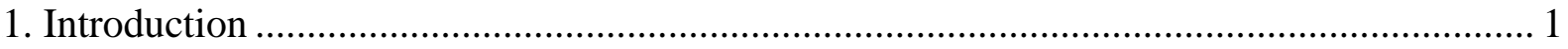

2. NGOs as Alternative Providers to the Excluded ............................................................... 2

3. Alternative services provided by NGOs................................................................................ 6

3.1 Defining alternative as non-formal? ....................................................................... 6

3.2 Pedagogical adaptations of alternative providers - alternative or complementary to

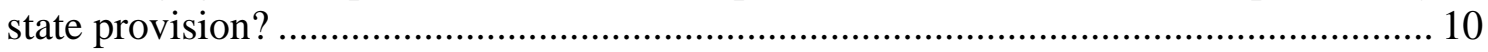

3.3 Accountability adaptations of alternative providers .................................................. 12

3.4 Alternative and conventional education provision - possibilities for convergence? 13 4. Experience of Non-government Provision of Alternative Service Delivery in International and National Policies and Plans ............................................................................................... 15

4.1 International commitments and goals .................................................................. 15

4.2 National policies and plans ................................................................................... 19

5. Experience of access in alternative and complementary education programmes ................. 26

5.1 Patterns in access to alternative education programmes............................................ 26

5.2 Cost-effectiveness of alternative education service delivery programmes................ 27

6. Scaling-up, Coordinating and Mainstreaming NGO Provision for Sustainability ................ 29

6.1 Scaling-up or mainstreaming 'alternative' / complementary provision ..................... 29

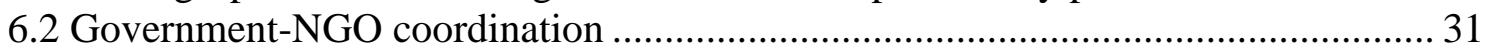

7. Conclusions and Proposals for Further Research................................................................... 34

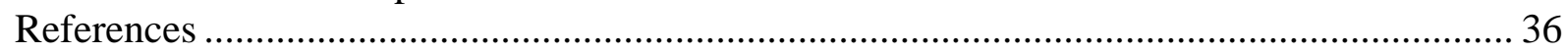

\section{List of Tables}

Table 1 Terms in the literature commonly associated with formal/non-formal approaches...... 8

Table 2 Areas for comparison of service delivery characteristics by provider ......................... 10

Table 3 Summary comparison of alternative provision in government plans............................ 22

Table 4 Comparing costs of schooling between complementary education programmes and government schools (\$) ............................................................................................. 28

\section{List of Figures}

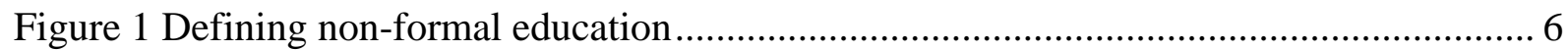

Figure 2 Short and long routes of accountability ………………………………………... 12

Figure 3 Summary of international influences on non-formal, alternative and complementary approaches to education

Figure 4 Assessment of alternative provision within India's Sarva Shiksha Abhiyan ............. 21

Figure 5: Recognition of alternative providers in Ethiopia's Education Sector Development

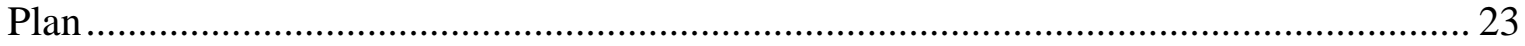




\section{List of Acronyms}

AIDS

AIE

BRAC

CAMPE

COBET

COPE

DANIDA

DFID

DPEP

EFA

EQUIP2

ESDP

FDRE

FE

FTI

GER

IE

IIEP

INGO

IRC

JICA

MDG

MICS

MOE

NFE
Acquired Immune Deficiency Syndrome

Alternative and Innovative Education

Bangladesh Rural Advancement Committee

Campaign for Popular Education

Complementary Basic Education and Training

Community Supported Primary Education

Danish International Development Agency

Department for International Development

District Primary Education Programme

Education For All

Educational Quality Improvement Program

Ethiopian Education Sector Development Programme

Federal Democratic Republic of Ethiopia

Formal Education

Fast-Track Initiative

Gross Enrolment Ratio

Informal Education

International Institute for Educational Planning

International Non-Governmental Organisation

International Rescue Committee

Japan International Cooperation Agency

Millennium Development Goals

Multiple Indicator Cluster Survey

Ministry of Education

Non-Formal Education 
NGO Non-Governmental Organisation

ODI Overseas Development Institute

OECD/DAC Organisation for Economic Co-operation and Development/Development Co-operation Directorate

PEDP Primary Education Development Programme

PRI Panchayati Raj Institutions

PRSP Poverty Reduction Strategy Paper

REBs $\quad$ Regional Education Bureaus

SCF-US Save the Children Federation United States

SC-UK Save the Children - UK

SWAps $\quad$ Sector-Wide Approaches

SIDA Swedish International Development Cooperation Agency

SPARK Skills, Participation and Access to Relevant Knowledge

SSA Sub-Saharan Africa

SSA Sarva Shiksha Abhiyan

UNESCO United Nations Educational, Scientific and Cultural Organization

UNICEF United Nations Children’s Fund

UPE $\quad$ Universal Primary Education

USAID United States Agency for International Development

VEC Village Education Committee 


\section{Preface}

This research review is one of a cluster of CREATE research outputs that address questions concerned with the roles that non-government providers can play in extending access to unserved children and communities. The sub sector is very diverse with many different forms of complementary and alternative provision. It receives support in many different ways from voluntary organisations, faith based groups, national governments and international development agencies.

The research highlights a set of key issues concerning educational process, governance, and the potential contribution that NGOs can make to expanded access in different contexts and the issues that surround the interfaces between NGO and government systems. Ideas from this paper are being used to shape empirical work undertaken within the framework of CREATE.

This is an important contribution a growing debate which takes on new urgency as it becomes clear that some populations by choice and some by necessity access basic education outside normal government school systems. Public authorities, at least in some countries, are becoming more uncomfortable with ideas of alternative provision and are beginning to emphasise the value strategies to deliver services making use of multiple providers. The implications of this need exploration and new analyses.

Professor Keith Lewin

Director of CREATE 


\section{Summary}

While access to state schooling has grown in many countries in recent years, a hardcore of marginalised children continue to be excluded from this. Some of these children are able to gain access to education through non-state provision. The focus of this paper is on primaryschool aged children who find access through (international) non-government organisations (NGOs). Based on a review of the available literature, the paper shows that there have been fluctuations in attention paid to NGO provision by education researchers since the 1970s. Changes are due in part to the prevailing political and economic environment, as well as to pressure placed on international agencies and national governments to reach education targets. The paper also shows that there has been a shift in the priorities of these providers over this period, from seeing themselves as supporting a parallel, alternative system of education independent of the state system, towards one aimed at being complementary to the state system, with the intention of ultimately supporting children's access to a state-provided education.

The paper highlights that much of the available literature suggests that NGO provision often intends to bring benefits in terms of the alternative forms of pedagogy and accountability it aims to offer. However, as the paper indicates, there is very little systematic, critical analysis of who is gaining access to education offered by alternative providers, or what they are actually getting access to. As such, there is a need for analysis of educational access to pay greater attention to diverse forms of access - both in terms of who provides, and what is provided. Moreover, changes in priorities associated with the effects of the international economic and political agenda, along with the intention of integrating multiple providers of education into a system-wide approach, give rise to the need for an analysis of the implications for NGO-government collaboration to ensure sustainability of educational access to those who would otherwise be excluded. 



\section{NGO Provision of Basic Education: Alternative or complementary service delivery to support access to the excluded?}

\section{Introduction}

The focus of this paper is on approaches by international non-government organisations (NGOs) to reaching primary school aged children excluded from any access to the conventional state education system. ${ }^{1}$ Approaches by NGOs to reaching these children are considered with respect both to the implications of their role as an alternative provider to the state, as well as of the alternative education services that they intend to offer. In particular, the paper reviews alternative forms of service delivery that have developed to adapt to the needs of specific forms of exclusion, primarily through provision of local and national NGOs supported by international NGOs and donor agencies. ${ }^{2}$ Such provision is most often aimed at sub-groups of populations who are not reached even where the state remains the main provider of education more generally. In some countries or areas, (international) NGOs may even be the main provider of education given that the state lacks capacity and/or will (including in fragile states). The paper highlights concerns that have arisen in recent years about the options that children face after participating in such alternative systems in terms of further education and livelihood possibilities, and so whether they have opportunities for social mobility. As the paper shows, these concerns are leading to the development of approaches to facilitate (re-)integration of what have been seen as alternative approaches with the formal state education system to develop a state-wide system drawing together multiple providers (both state and non-state) - with awareness of the blurred boundaries between these. ${ }^{3}$

The paper reviews the possibilities and implications of integrating different forms of provision in this way. It considers in particular ways in which (international) NGOs and governments are able to collaborate and the obstacles to this since, by giving (international) NGOs credibility through recognition, governments could undermine their own role and status and, therefore, their legitimacy.

Two areas of the debate are brought together in the paper with the aim of promoting sustainable access to education for those currently excluded from state provision. First, some educationalists recognise the benefits that alternative approaches to education service delivery can bring, and seek ways to scale these up to achieve Education for All (EFA) goals either through non-state provision and/or through adapting state provision. Second, governance

researchers are concerned with the implications that a renewed focus on multiple forms of provision has on (changing) engagement between (international) NGOs and governments. For

\footnotetext{
${ }^{1}$ This relates to Zone 1 of CREATE's conceptual framework - i.e. those denied access to conventional schooling. It can also include those children in Zone 2 - i.e. who gain initial entry but drop out in the early grades. If/when children enrolled in NGO provision are subsequently integrated into the conventional state system, they are likely to become part of Zone 3, i.e. at risk of dropping out.

See http://www.create-rpc.org/about/conceptual_background.shtml for further explanation of the CREATE zones.

${ }^{2}$ Alternative approaches are often designed for adult education programmes, with a focus on adult literacy. However, these are beyond the scope of this paper. There is also a growing trend of referring to out-of-school 'youth'. These are covered in this paper where they are of an age that would allow them to re-integrate within the formal system at either the primary or secondary level.

${ }^{3}$ This paper is complemented by a paper on 'Supporting non-state providers in basic education service delivery' (Rose, 2006) which reviews different types of providers of education, highlighting that boundaries are often blurred with respect to their funding, management and regulation. This paper focuses more specifically on (international) NGO provision.
} 
the purposes of this review, literature has been drawn from available academic sources within education and development studies journals, as well as from publicly-available international agency literature (including of NGOs and bilateral and multilateral agencies). Analysis is also undertaken of international and national policies and plans, focusing in particular on national plans associated with CREATE partner countries. As the paper shows, much of the literature on NGO provision is written from the perspective of international agencies advocating for this form of provision. As such, it can lack a critical perspective, and so needs to be considered with some caution. While there is a sizeable academic literature within the field of development studies on NGO-government relations, this rarely addresses the implications with respect to education specifically (and where it does, it can often consider education superficially). Education literature has not paid sufficient attention to the implications of these relationships for EFA.

The paper begins by reviewing the role of (international) NGOs involved as alternative providers to the excluded. It then considers the alternative forms of education services they provide in order to reach those otherwise excluded from basic education. It explores reasons for the rise in (international) NGO provision in the light of international education, economic and political priorities as advocated by multilateral and bilateral agencies, and the implications of this for the changing ways in which their provision is addressed in international and national policies and plans. Features of specific (international) NGO programmes, including their patterns of access and cost-effectiveness are then discussed. Finally, issues related to mainstreaming and scaling up these programmes to ensure sustainability of access is considered, with particular attention to the implications for NGOgovernment coordination. The paper concludes by identifying research gaps within the literature under review.

\section{NGOs as Alternative Providers to the Excluded}

Basic education is commonly regarded as a state responsibility. Internationally-agreed EFA goals specify that primary schooling should be free and compulsory (in line with the 1948 United Nations Declaration of Human Rights), with legislation in many countries to support this. Such targets have been evident since UNESCO (United Nations Educational, Scientific and Cultural Organization) regional conferences in the 1960s which set targets for universal primary education (UPE) by 1980. The focus of these targets was on increasing access of children to formal schooling provided by the state. The role of the state in basic education service delivery is considered relevant both given education's strategic importance in national identity formation, as well as due to the benefits that accrue in terms of social and economic development (Colclough 1982; Lewin, 1995; Hannum and Buchmann, 2005). For individuals and households, these benefits are anticipated to develop over a lifecycle and across generations (Rose and Dyer, 2006; Harper et al., 2003). In countries affected by conflict and 'fragile states', ${ }^{4}$ the imperative for education is often even greater, as not only is it a right and a contribution to the development and growth agenda, but can also be important for ensuring security (Rose and Greeley, 2006).

On the one hand, state involvement intends to promote its legitimacy - where legitimacy is understood as the ability of the government to work in the interest of the public and demonstrate fairness to all groups in providing security and services. Education is a

\footnotetext{
${ }^{4}$ OECD DAC characterises fragile states as countries with poor governance as identified by a lack of political commitment and/or weak capacity to develop and implement pro-poor policies; fragile states also often experience violent conflict (see Rose and Greeley, 2006).
} 
particularly key service sector given it is the largest, most widespread and visible state institution in the country, evident even in remote regions. On the other hand, it is also one of the most difficult institutions to govern and manage given its size, as well as its cultural, social and economic dimensions. Thus, even where legislation stipulates the state's responsibility to free and compulsory basic schooling, it is often not possible to provide universal access through state provision alone. Moreover, where state provision has been inadequate to fulfil demand, non-state provision has grown by default to fill the gap (see, for example, Lewin and Sayed, 2005; Rose, 2005).

With renewed focus on expanding primary schooling particularly since the 1990 Education for All (EFA) commitments and in line with the education Millennium Development Goals (MDG), greater attention is being paid by some donors and governments to the role that nonstate providers are and could play in supporting the state in achieving targets, while continuing to view the state as the main provider. This invites consideration of the changing role that the state needs to play in supporting basic education service delivery in situations where it is not the direct provider, while maintaining its legitimacy.

The implications of the state's role differ according to the type of non-state provider, and the extent to which the services they offer are intended to be complementary to, or substitutes for, state provision. ${ }^{5}$ This paper is particularly concerned with those most under-served by the state system, for whom alternative models of service delivery have been developed primarily with the support of (international) NGOs.

NGOs play different roles in supporting education service delivery. Some NGOs are primarily involved in advocacy aimed at putting pressure on governments fulfil their commitment to ensuring access for all children to an education of acceptable quality (Mundy, 2001). Some NGOs, which form the focus for this paper, are involved directly in provision, primarily with respect to providing education to the excluded. Educational exclusion can take many forms, including those 'hard-to-reach' with respect to gender, street children, orphans, child soldiers demobilised children in post-conflict areas, pastoralists, indigenous groups, language, faith, disability, refugees, child labourers etc. (Sayed and Soudien, 2003; UNESCO, 2004). These forms of exclusion may interact with income-related poverty, but can also result from children not being able to go to school for socio-cultural and other demand-side related reasons (Colclough et al., 2003). Inadequate supply of schooling in remote, rural areas can further exacerbate these constraints. As a result, even in countries where overall enrolment appears reasonably high, there are often pockets of exclusion, which may be sizeable in some rural parts of the country, and also evident in urban areas. Such provision is usually localised on a small scale, with the intention of developing innovative approaches to reach those otherwise excluded from the conventional state system.

In some cases, NGOs may be the main provider of education, particularly where state willingness and/or capacity is weak, as in many conflict areas and 'fragile states'. This is particularly apparent where the state lacks legitimacy, and so international agencies are unwilling to place aid through their budgets, and so divert resources directly to the source at which the service is delivered (Rose and Greeley, 2006). Given that state systems have been unable to reach out to those most marginalised from education even in relatively high enrolment countries, and some estimates that as many as a third to one-half of children out of

\footnotetext{
${ }^{5}$ Commercially-driven private providers have also become a focus of attention in the context of achieving EFA goals. With respect to primary education, recent work has indicated that these providers play a role in giving a choice for those who can afford to pay where state schooling is perceived to be of low quality, rather than filling a gap where no other provision is available (see Rose, 2006 for a review; and Lewin and Sayed, 2005, for analysis of related issues at the secondary school level).
} 
school live in fragile states (Colenso, 2005; FTI, 2005), NGOs potentially play a key role in the achievement of EFA and MDG goals.

This form of NGO provision is however a relatively recent phenomenon. It has grown significantly in the context of the international policy agenda of the 1980s and 1990s associated in particular with the Washington and Post-Washington Consensus (see Fine and Rose, 2001). The international agenda have directed attention towards economic liberalisation and democratic governance, one implication of which is a growing trend by donor agencies since the 1990s to channel aid to developing countries through international NGOs (Edwards \& Hulme, 1995). In the mid-1990s, it was estimated that around 10-15 percent of all official aid to developing countries was channelled through NGOs. The United Kingdom, for example, increased the amount of its official aid channelled via NGOs by 400 percent over the decade 1983 to 1993. Although emergency assistance accounts for a significant proportion of aid allocated to NGOs, the majority is allocated to development projects and programmes (ODI, 1995). In practice, it can be difficult to identify how much aid is provided to NGOs, and there is a notable lack of analysis of the allocation of aid to NGOs for education projects and programmes specifically. This requires attention in order to provide a picture of the scale of the involvement of NGOs within the sector.

While NGO provision is often associated with non-profit motivation, with the terms NGO and non-profit sometimes used interchangeably, it can take many forms. Motivations of NGOs can vary depending on whether they are established as 'beneficiaries', 'mercenaries', 'missionaries' or 'revolutionaries' (Malena, 2000). For some, NGO provision is defined more narrowly to refer to those organisations receiving funds from international aid agencies, but which are institutionally separate from the state apparatus and are non-profit distributing (Tvedt, 1998, cited in Bano, 2006). Not infrequently, such NGOs are established specifically as a means to acquire donor resources (Miller-Grandvaux et al., 2002). Even though their registration status means they cannot distribute profit officially, those working for the NGO are beneficiaries of donor resources. They may, for example, receive preferential salaries to those supporting the state education system, implying that their motivation can be financial rather than philanthropic. In many cases, funds are channelled by international aid agencies through international NGOs to national NGOs who implement the projects. Where NGO approaches have developed nationally rather than through international NGOs, such as the case of BRAC in Bangladesh, one of the motivations of their involvement in education is reported to be related to a small (but growing) educated urban elite which has a strong commitment to modern education for the masses for instrumental reasons (i.e. to transform behaviour and attitudes of the poor in ways which are likely to have broader benefits) (Hossain et al, 2002).

NGO provision is sometimes also seen as synonymous with 'community schooling.' For the purposes of this paper, 'community schools' refer to those schools established by communities themselves, without external support of NGOs (or donors funding them). ${ }^{6}$ Many countries have a long tradition of such community schools (Bray and Lillis, 1988). More recently, community involvement has been advocated as a means to provide resources in response to cutbacks in government expenditures following structural adjustment and associated liberalisation programmes since the 1980s (Bray, 2003; Rose, 2003a). In recent years, it is not uncommon for spontaneous community schools to be established where other forms of provision are lacking, and these are particularly evident in conflict situations or fragile states. The expectation of communities is often that the state will take over responsibility for provision once it has been established and legitimised. In such situations, international NGOs frequently become the intermediary between communities and the state.

\footnotetext{
${ }^{6}$ Bano (2006) makes an important distinction between NGOs supported by aid resources and those relying on domestic donations, which are referred to in her paper as traditional voluntary organisations.
} 
This may either result in the international NGO taking over the community's role in provision and/or ensuring that the community provision is recognised in state plans as they develop. ${ }^{7}$

\footnotetext{
${ }^{7}$ One example of this is in Afghanistan where, during the Taliban period, girls were systematically excluded from government schools, resulting in spontaneous local initiatives by women who set up 'schools' in their homes. These home-based schools subsequently became supported by INGOs (including CARE and the International Rescue Committee), and are now being integrated into state systems (Kirk and Winthrop, nd).
} 


\section{Alternative services provided by NGOs}

\subsection{Defining alternative as non-formal?}

In order to reach the excluded, NGO providers often aim to develop 'alternative' forms of education to the formal 'conventional' state system, in order to address particular aspects of exclusion. This gives rise to questions of what is seen as 'conventional' and what is an 'alternative' to this. The 'alternative' associated with (international) NGOs is often related to what has been referred to as 'non-formal' approaches. Coombs and Ahmed's seminal book (1974) provides the first systematic, critical analysis of such non-formal education programmes (focusing mainly on adult education - including in particular programmes aimed at increasing rural employment, productivity and income of farmers, rural artisans and crafts workers and small entrepreneurs). As a basis for this, their book articulated a now much cited definition for non-formal education, starting from the premise that 'education can no longer be seen as a time-bound, place-bound process confined to schools and measured by years of exposure' and so equated education with learning, regardless of where, how or when learning occurs (Coombs and Ahmed, 1974: 8) (Figure 1). As the authors note, there are similarities between formal and non-formal education in as much as they may be organised to augment and improve the informal learning process; as well as differences with respect to their sponsorship and institutional arrangements, and often in their educational objectives, and the groups they serve. Interestingly, these definitions do not raise issues of who provides the different forms of education, although the term non-formal education has become closely associated with NGO forms of provision, while formal is seen to refer to state provision.

\section{Figure 1 Defining non-formal education}

Informal education...is the lifelong process by which every person acquires and accumulates knowledge, skills and attitudes and insights from daily experiences and exposure to the environment - at home, at work, at play; from the example and attitudes of family and friends; from travel, reading, newspapers and books; or by listening to the radio or viewing films or television. Generally, informal education is unorganized and often unsystematic; yet it accounts for the great bulk of any person's total lifetime learning - including that of even a highly 'schooled' person.

Formal education....is, of course, the highly institutionalized, chronologically graded and hierarchically structured 'education system,' spanning lower primary school and the upper reaches of the university.

Nonformal education...is any organised, systematic, educational activity carried on outside the framework of the formal system to provide selected types of learning to particular subgroups of the population, adults as well as children. Thus defined, nonformal education includes, for example, agricultural extension and farmer training programmes, adult literacy programs, occupational skill training given outside the formal system, youth clubs with substantial educational purposes, and various community programs of instruction in health, family planning, cooperatives and the like.

Extracted from: Coombs and Ahmed, 1974: 8.

The term non-formal education has gained common currency, with the definitions coined by Coombs and Ahmed continuing to be adopted by international agencies (see, for example, UNESCO, 2006b). However, debates amongst education researchers about terminology have 
arisen in recent years - in part in the context of concern that the terms 'non-formal' and 'alternative' imply second-best, and in part because the diversity of forms of programmes, and changes in the formal system itself, has made boundaries between formal and non-formal increasingly fuzzy - and potentially meaningless (Hoppers, 2006). As Rogers (2004) suggests:

the term non-formal education now covers a very wide continuum of educational programmes. At one extreme lies the flexible schooling model - national or regional sub-systems of schools for children, youth and adults. At the other extreme are the highly participatory educational programmes, hand-knitted education and training, tailor-made for each particular learning group, one-off teaching events to meet particular localised needs. Most educational programmes will of course lie somewhere between these two points. But to include both kinds of provision under the heading of non-formal education tends to lead to confusion, for they are very different in spirit and in form.

Such confusion is further exemplified by definitions associated with alternative approaches where these are seen as 'learning which is categorized by flexibility, capacity to recognize and creatively utilize diversity, and transparency in terms of the degree of openness - open access, open learning and limitless opportunities to release the creative potential of learners (Thompson, 2001: 4). Thompson (2001) sees the alternative approaches in evidence today as originating from indigenous approaches evident prior to colonial times. In his view, alternative forms of learning have been an important part of the processes of socialisation in Africa, with the content of learning determined by functional needs of learners, with respect to relevance, contextual, cultural and social features etc. As such, Thompson (2001: 9) proposes that 'The current forms of alternative approaches are firstly, the direct results of the dysfunction of a de-culturated mainstream formal education; secondly the desire of communities and groups to decide what and how their children must learn; thirdly, the developments at the regional and global levels e.g. the Education for All Initiative and other regional initiatives which have implications for education and lastly, the impact of educational philosophical thoughts.'

As Thompson (2001), Hoppers (2006) and many others note, in principle attributes associated with 'alternative' approaches could apply to both formal and non-formal learning environments. A common concern is whether and how these could ultimately become integrated within a system-wide approach to education. This is not a new question. Thirty years ago, Coombs and Ahmed (1974) envisaged that 'rural education systems should ultimately blend formal and non-formal components, relevant to the realities of its participants' lives and needs, flexible and adaptive to changing needs, and accessible to motivated learners of any age or sex. It should not be intellectually second-class; it should have its own standards of excellence geared to its different purposes and clienteles and to the circumstances of its society' (Coombs and Ahmed, 1974: 216). As such, the 'alternative' which is frequently associated with terms such as 'innovative'; 'flexibility' etc. would become the 'convention'. This has raised questions of why this has not occurred. Some suggest that the distinction can and should be overcome through the adoption of a 'lifelong learning' approach which interweaves formal/non-formal and informal approaches - with lifelong learning having been the preferred choice of terminology in the North, where the term nonformal education has rarely been used (Rogers, 2004; Hoppers, 2006; Torres, 2001).

Torres (2001: 4) further challenges the use of the term 'alternative' for distinguishing between formal and non-formal education, and suggests consideration of the following:

- 'There are alternatives within FE [formal education] - not only alternatives to it; 
- The alternative to bad FE is not good NFE [non-formal education] but good FE. (If NFE is the alternative to bad FE, what is then the alternative to bad NFE?);

- The role of NFE is not to complement FE. FE, NFE, IE [informal education] complement each other throughout the life of an individual as well as in a holistic education policy;

- NFE is not self-targeted to the poor, the poorest of the poor and to the most disadvantaged of the disadvantaged. It is and must be viewed as an education and learning channel that is needed and that is good for all;

- NFE is not remedial or compensatory in nature, addressed to those who do not have a chance to go to a 'regular' school or who could not do it 'on time'. NFE has value in its own right, and is necessary and useful for both basic and continuing education.'

Torres (2001:5) further suggests that 'Many of the characteristics typically attributed to NFE, when contrasted with FE - such as flexibility, school-community linkages, openness and responsiveness to the needs and possibilities of the learners and to specific contexts and cultures, etc. - are characteristics that describe good education, regardless of the specific modality it adopts... All those characteristics should not be viewed as 'innovations', or even as options; they should be the norm in all types of education and learning institutions' (Emphasis in original). Where formal and non-formal education converge, Torres (2001) suggests changes can be evident with respect to 'deformalizing formal education' along with 'formalizing non-formal education.'

On the one hand, 'non-formal education' has become associated with second-best education, and is trying to shake off this image by being identified as something in its own right rather than being seen as 'not' the norm. On the other hand, terms commonly associated with nonformal education in literature (often written by proponents of non-formal education) are ones that are usually identified with 'good' quality education, while those associated with formal schooling have been given more negative connotations. Table 1 summarises some of the language frequently used in documents to refer to each of the types.

Table 1 Terms in the literature commonly associated with formal/non-formal approaches

\begin{tabular}{|l|l|}
\hline Formal & Non-formal \\
State provided & NGO provided \\
Conventional & Alternative / Complementary \\
Mainstream & Compensatory / Supplementary \\
Accountable to Ministry of Education & Accountable to civil society/community \\
Teacher-centred & Child-centred \\
Homogenous & Heterogeneous \\
Rigid & Flexible / participatory \\
Top-down & Bottom-up \\
Over-crowded curriculum & Accelerated learning \\
Modernisation & Locally relevant \\
\hline \multicolumn{2}{|c|}{ Responsive schools } \\
\hline
\end{tabular}


The comparisons in Table 1 present extreme views that could be contested. This is in part because much of the available literature on the comparisons is written by agencies advocating for non-formal approaches, and so the conclusions drawn need to be considered with caution. As Molteno et al (1999) note, in a report prepared jointly by an international agency (the UK Department for International Development - DFID) and leading international NGO (Save the Children-UK), problems encountered in adopting different approaches designed by (international) NGOs are rarely documented. The authors argue that more attention is given to the positive experiences (as they recognise as being a limitation of their own report) given political difficulties in agencies raising problems which might involve criticising governments with which (international) NGOs are trying to partner, or endangering resources available to international NGOs reliant on donor money who need to display positive results. This is no doubt a reason why there are very few, critical, assessments of such initiatives available more generally.

Attributes of formal provision could be associated with positive images of a more professionally-developed, regulated system with the aim of providing children with access to jobs in the formal sector, compared to a non-formal system where there is little external monitoring, with learning limited to basic literacy and numeracy, thus meaning that children cannot move beyond their existing environment and status. However, these contested views are rarely portrayed in recent literature, where it appears that there is almost a fear of being critical about an approach that has gained exemplary status in the eyes of some international agencies. ${ }^{8}$ Importantly, as later sections of this paper indicate, there is limited rigorous evidence undertaken by non-partisan researchers which supports some of the views put forward in favour of non-formal education.

Even though different 'alternative' programmes have a range of target populations, in reality there are often similarities in the ways in which they adapt their service delivery. Table 2 compares characteristics of a conventional state formal schooling model evident in many developing countries with intended characteristics of non-formal education provided by (international) NGOs. The table highlights some of the areas where differences in service delivery of different providers might be observed. There is clearly more diversity within each of the forms of provision than illustrated in Table 2. For example, state provision can include small class sizes, particularly in higher grades and in more remote areas, where multi-grade might be practised.

\footnotetext{
${ }^{8}$ See, for example, UNESCO, 2006b, which reproduces a table comparing formal and non-formal approaches, associating the former with negative attributes of passive and decontextualised learning, and the latter with problem-solving approaches developed in a meaningful context.
} 
Table 2 Areas for comparison of service delivery characteristics by provider

\begin{tabular}{|l|l|l|}
\hline \multicolumn{1}{|c|}{ Alternative provider } & \multicolumn{2}{c|}{ NGO } \\
\cline { 1 - 2 } Geographical coverage & & \\
\hline School/class size & National/mass system & $\begin{array}{l}\text { Excluded, marginalised, } \\
\text { disadvantaged }\end{array}$ \\
\hline Curriculum & Large to small & very small \\
\hline Assessment & Government & Adapted from government \\
\hline Language of instruction & School leaving certificates & On-going, formative assessment \\
\hline Timetable & National/local & Local \\
\hline Recruitment of teachers & Structured/inflexible & Flexible - seasonal adjustments \\
\hline Payment of teachers & National & Community-based \\
\hline Teacher training & Civil service pay scale, permanent & 'Voluntary' \\
\hline
\end{tabular}

In practice, there is often a standard version of an alternative or complementary programme, rather than a wide variation of 'flexible' approaches as implied in much of the non-formal education literature (and indicated in Table 1). A USAID (United States Agency for International Development) assessment of NGO education programmes in Ethiopia, Guinea, Malawi and Mali (where USAID is supporting national NGOs through SCF-US (Save the Children Federation - US)) argues that the roles of the programmes are similar across the four countries. Most are working at the community level to mobilise parents and other local nongovernmental actors to improve conditions and accountability at school levels (MillerGrandvaux et al., 2002). Moreover, Bano (2006) describes in more detail how NGOs in Pakistan have adopted the term non-formal education with respect to the role of the community in decision-making rather than in terms of innovative pedagogical practices.

\subsection{Pedagogical adaptations of alternative providers - alternative or complementary to state provision?}

While there is some similarity in characteristics of non-formal education programmes provided by NGOs, there may be differences in the ways in which they adapt pedagogical approaches, depending on whether they intend to develop particular skills, or provide accelerated learning for basic literacy and numeracy, for example (Mfum-Mensah, 2003; Hoppers 2006; Carron and Carr-Hill, 1991). While NGO providers have commonly been associated with intending to provide an alternative form of curriculum to the state system, more recently they have become associated with 'complementary' (or 'para-formal') approaches. This indicates a shift towards an intention to promote equivalency with the government system by, for example, adopting a similar curriculum while focusing on particular subjects to enable 'accelerated learning'. The term accelerated learning is also a term open to different interpretations, including approaches which support a reduced curriculum compared with the state system focusing on basic literacy and numeracy; or systems offering a different kind of/additional curriculum - such as peace education, civic education etc. (Balwanz et al, 2006); or 'using learner-centered teaching principles and 
practices to creatively engage students' multiple learning systems, resulting in faster, deeper, and more proficient learning (Charlick, 2005: 7).

USAID has recently adopted the terminology of 'complementary' programmes, suggesting that such programmes are appropriate where there are overcrowded classrooms in the state system, children out of school due to seasonal work, and/or no other opportunity of schooling such as in remote areas or areas affected by conflict. However, here the alternative approach is adopted in recognition of attempting to address difficulties of changing the state system (rather than considering the alternative as second-best). As a USAID-sponsored paper notes, accelerated learning can be of relevance where 'national leaders are or can be persuaded that significant change is needed and possible in their educational system in order to attain the student achievement goals they desire for their country's future' (Charlick, 2005: 4). Examples of complementary, accelerated learning approaches of this kind include Ghana's School for Life programme which has designed the curriculum to cover the first three years of primary school in nine months, and Zambia's 'Skills, Participation and Access to Relevant Knowledge' (SPARK) was developed as an alternative curriculum for older children, compressing seven years of the curriculum into four years (DeStefano et al, 2005).

'Alternative' provision may aim to support different types of life skills to those in the formal system (professional and vocational training programmes); or aim to provide additional support to young children who might still have the opportunity to gain access to the formal system but require a particular kind of support to enable them to do so (supplementary nonformal education for AIDS orphans, children affected by conflict or abuse). For example, in Afghanistan home-based schools aim to provide psychosocial support for children affected by violent conflict. As such, some forms aim to 'cram' the formal curriculum into a shorter period (focusing on basic literacy and numeracy), others aim to provide different kinds of skills to those offered in the formal system, while others intend to link more directly with training for particular kinds of occupations. Some approaches target particular population groups, while others target particular types of knowledge and skills (Mfum-Mensah, 2003). Within this disaggregation of types, 'alternative' non-formal education is understood as one which is implemented as a different education model, in a way that is more relevant to the basic education needs of young people, altering the structure of education to increase access, relevance and efficiency (Mfum-Mensah, 2003). As such, the alternative approach could be adopted across the different types of non-formal programmes.

USAID's recent comprehensive study of programmes aimed at 'complementing' the state education system in eight countries explicitly notes that these are 'not meant as non-formal alternative programs' (DeStefano et al, 2006: 8) even though some were referred to as nonformal programmes at the time when they were established. In Zambia, given the SPARK curriculum was not examinable, there has been a move towards community schools using the national curriculum, and an equivalency system is currently being devised in Bangladesh to allow graduates from NGO programmes to join the formal system (DeStefano et al, 2005). In the case of Mali, USAID facilitated the formal recognition of the community schools it has supported, with equivalence being established in principle, although it has not achieved harmonisation between the two systems in terms of approach (Hoppers, 2006). Thus, there are increasingly similarities between some formal and complementary approaches in terms of the curriculum followed in order to prepare for higher levels of education, with complementary approaches converging towards government, rather than the other way around. However, the challenge of integrating graduates from these programmes into the formal system has not yet been resolved - both in terms of the different experience of learning styles and social background of students which can result in them being excluded within the formal schools, as well as limited availability of these schools which often gave rise to the alternative / complementary versions in the first place. 
Furthermore, the shift towards seeing NGO provision as complementary to state provision, with the aim of ultimately integrating graduates into the state system, gives rise to the need of non-state providers gaining recognition (and support) from government for the services they provide (see Section 6).

\subsection{Accountability adaptations of alternative providers}

Adaptations in service delivery of NGO providers also aim to influence pathways of accountability between citizens (particularly parents of school-aged children), education providers and the state. Where the state is provider, a long-route of accountability is most often evident, where the state responds to the needs and expectations of citizens to ensure appropriate provision. However, this long-route may be problematic in fragile states, and also in particular areas of a country where the state is unable or unwilling to respond. In such circumstances a short-route of accountability may develop, with providers responding directly to the needs and expectations of citizens (Figure 2). A long-route of accountability is generally viewed as the ultimate aim, in order to ensure legitimacy, and benefits of social provision based on democratic governance (World Bank, 2004).

\section{Figure 2 Short and long routes of accountability}

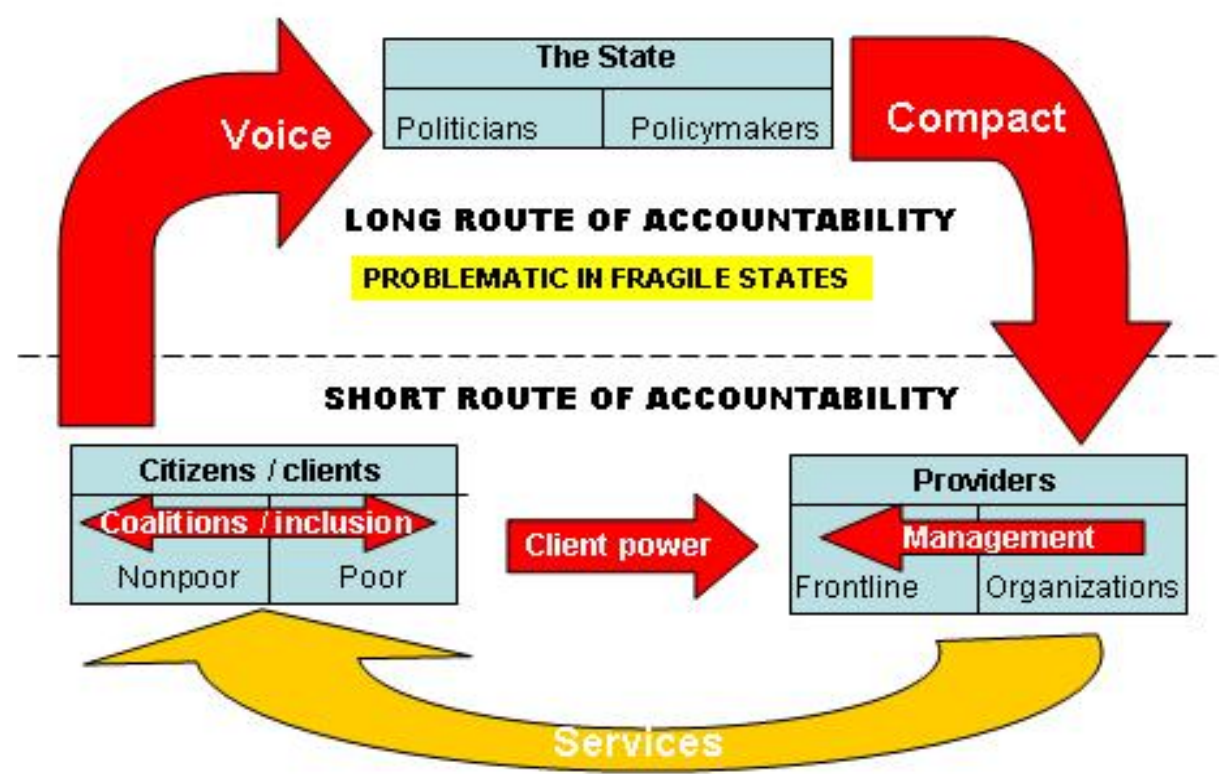

Source: Meagher, 2005, adapted from World Bank (2004: 49)

For some (international) NGO providers (and international aid agencies supporting them), adaptation of accountability to the short route is seen as advantageous in its own right. By working closely with communities they serve, providers see benefits in strengthening local accountability both to influence demand for education, and also ensure its relevance to those being served. One approach to achieve this is through (international) NGOs supporting communities to establish their own schools (DeStefano et al, 2006). However, reliance on short-route accountability in this way has, in reality, been found to be a form of extraction from poorer communities in some sub-Saharan African countries, where communities have been expected to provide support in the form of materials and labour (even though the 
intention has been to empower the communities to hold schools more accountable) (Bray, 2000; Rose, 2003a).

There are many examples of blending long- and short-route accountability through school committees and parent-teacher associations in formal schools. As such, the World Bank, for example, proposes that attempts can be made to promote accountability within fee-free government provision through improving community-school relations (World Bank, 2005). This might include strengthening of school management committees, parent-teacher associations etc. which often exist in some form in many countries, although with varying degrees of success. While recognising problems with short-route accountability in the formal state system associated with the extent to which members of communities are willing and able to be involved, as well as elite capture within communities, these challenges are as likely to be evident through alternative approaches as they are within the state system.

\subsection{Alternative and conventional education provision - possibilities for convergence?}

As noted, the ultimate aim of alternative provision has increasingly become seen as being merged with the conventional formal system, rather than seeing it as 'alternative'. To the extent that the alternatives are due to who is providing, rather than what is provided, this gives rise to questions of whether 'state education systems [are] unable to adapt their operations, programmes and structures to face and address the challenges of access to quality basic education in poor and hard to reach areas of society' (Akyeampong, 2004: 42). It also raises questions of whether NGO programmes offer experiences that might be beneficial for integration into state systems.

As noted in Section 3.2, there is limited rigorous analysis of NGO programmes. It is also apparent that a small number of programmes deemed to be successful (often ones that have expanded in coverage, and sometimes replicated elsewhere) are frequently cited - including School for Life in Ghana, and BRAC in Bangladesh. Others that are not seen as successful in terms of the quality of their provision are hardly referred to (or might still be referred to in a positive light). ${ }^{9}$ According to Thompson, (2001) the majority of non-formal education programmes fall into the latter category. Given the lack of systematic, critical analysis based on a diversity of programmes (beyond the well-known 'good practice' examples), it is not possible to draw conclusions to support either claims of innovation with respect to adaptations of pedagogy and accountability of NGO programmes, or that in reality these do not achieve their intended objectives.

DFID/SC-UK (Save the Children - UK) research suggests that possibilities for convergence between the alternative and conventional providers and types of provision can lie in promoting responsive schools (Molteno et al, 1999). As the report implies, without attempts to finding ways to support the responsiveness of national systems, it is possible to become sceptical of 'innovative' approaches - since many of these have now been developed for some time, and are at most being replicated in different contexts and can no longer be considered as 'new' ideas. The study goes some way in attempting to bridge the divide between alternative approaches provided by NGOs and supporting state schools to be more responsive through three different approaches: proposing alternative models of state provision, working with state systems at their weakest points to demonstrate that even there change is possible, and support communities to make the state system more accountable and responsive (Molteno et al, 1999). This implies NGOs taking on more diverse roles - beyond 'piloting' innovative approaches.

\footnotetext{
${ }^{9}$ One example of this is the SC-US-supported Village-based Schools programme in Malawi which is not considered a success within the country (Kadzamira and Rose, 2004), but is referred to in a positive light in a recent USAID document, drawing on out-dated literature (DeStephano et al, 2005).
} 
The possibilities for integrating NGO innovative practices within state provision in the way implied requires further consideration of government-NGO forms of collaboration, as discussed in Section 6. 


\section{Experience of Non-government Provision of Alternative Service Delivery in International and National Policies and Plans}

\subsection{International commitments and goals}

Attention in international literature to the meaning and role of 'alternative' approaches to reaching those excluded from the state system has re-emerged over the last decade, having become a focus in the 1970s and early 1980s as it was becoming apparent that the 1980 UPE targets would not be met. The renewed attention is in part due to the emphasis placed at the 2000 World Education Forum in Dakar, with concern being raised that alternative provision should be given appropriate status if it is to contribute to EFA.

Coombs and Ahmed's study (1974) gave rise to more emphasis on non-formal education in the World Bank and amongst the international agencies more generally. Their study was motivated by the 'lopsided pattern' of development efforts which they argued had prioritised modernisation of urban areas, giving rise to a widening social and economic gap between urban and rural areas with education seen as partly responsible for this. Moreover, their study came at a time when standardised formal approaches to schooling were becoming heavily criticised from a variety of perspectives (including Illich's 'deschooling'; Friere's 'critical consciousness'; Dore's 'diploma disease'; Bowles and Gintis' reproduction of social relations in schools analogous to 'mini factories'). Furthermore, it was written in the light of the anticipation that the 1980 UNESCO UPE targets would not be reached, implying alternative approaches would be needed. Despite the importance of the study, spending patterns of the World Bank were not re-directed towards non-formal approaches (Jones, 1988).

Attention to the non-formal education 'fashion' appeared to become 'more sober' in the late 1980s, as 'Attention in international agencies has partly swung back to the formal system and ways to reform and spread it as widely as possible' (Bray, nd: 99). More recently, renewed attention on alternative approaches is an attempt to address concerns that the 2015 EFA/MDG targets will not be met through the formal state system alone, and so the search for costeffective, non-state approaches has reignited. As Hoppers (2006) notes, attention to nonformal, alternative approaches was still not apparent post-Jomtien, but is now gaining greater recognition post-Dakar as momentum from this, combined with the MDGs, has heightened concern to speed up progress towards EFA goals. As he notes, for the first time debates within international agencies around non-formal education are as strong, or stronger, than they were in the 1970s - and there now appears to be recognition of ways in which non-formal education can potentially contribute to these goals.

Since Coombs and Ahmed's (1974) study, there have also been important changes in the political and economic environment for many countries that are in danger of not meeting targets - some of which are still trying to overcome the effects of economic crises and associated structural adjustment programmes during the 1980s, and some having moved towards democratic processes in the light of the 1990s governance agenda, with education often playing an important role in election campaigns (Fine and Rose, 2001; Rose, 2003c). International agencies have had an important role to play in changing priorities towards education over this period, both directly through conditions placed on countries receiving aid, as well as indirectly through the setting of international targets etc. (King and Rose, 2005). In the light of changes in the 1980s, non-formal education declined in popularity. It is argued that it became seen as a 'band aid' to maintain social structures and avoid reform, by having alternative schemes for unemployed youth in urban slums to try and quell conflict, for example, rather than addressing the root causes of conflict (Carnoy, 1982, cited in Bray, nd). This perspective is arising once more in the context of the focus on education for youth for 
security reasons in fragile states (Rose and Greeley, 2006). Interest in non-formal education approaches has revived in international agency discourse since the 1990s. As will be seen, NGO provision has also become increasingly recognised in government education plans in recent years. Reasons for this relate to the Post-Washington Consensus agenda of democratic governance and economic liberalisation, providing space for non-state providers to play a role in social service delivery. Support for the involvement of non-state providers, including NGOs, is reinforced by concern that, once again, internationally-set targets will not be met unless different approaches are considered.

The Declaration at Jomtien continued to view non-formal education for children and youth as gap-filling for malfunctioning formal primary schools, thus reinforcing the established hierarchy of seeing non-formal as second-best (Hoppers, 2006):

Supplementary alternative programmes can help meet the basic learning needs of children with limited or no access to formal schooling, provided that they share the same standards of learning applied to schools, and are adequately supported. (UNESCO, 1990. Emphasis added).

Otherwise, the Declaration noted the diverse learning needs of youth and adults that could be met through a variety of delivery systems, relating non-formal education with literacy programmes. By contrast, Dakar was more forthcoming in recognising the contributions that alternative programmes could make to achieve Goal 2 associated with 'ensuring that by 2015 all children, particularly girls, children in difficult circumstances and those belonging to ethnic minorities, have access to and complete free and compulsory primary education of good quality':

All children must have the opportunity to fulfil their right to quality education in schools or alternative programmes at whatever level of education is considered 'basic' (UNESCO, 2000. Emphasis added).

However, as the following sentence in the Declaration indicates, commitment to alternative programmes is ambiguous, as emphasis continues to be placed on state-provided primary schooling:

All states must fulfil their obligation to offer free and compulsory primary education in accordance with the United Nations Convention on the Rights of the Child and other international commitments. (UNESCO, 2000. Emphasis added).

Moreover, non-formal education is only mentioned in the Declaration as a strategy with respect to adult education, although it does note the need for improved regulatory mechanisms for non-formal primary education. In practice, this aspect has received very little attention by donor agencies and national governments, with neither appearing to show commitment through the allocation of resources on any scale.

The main focus on formal, state-provided schooling is reinforced in UNESCO Global Monitoring Reports which discuss progress towards Goal 2 in terms of formal schooling. In looking at educational quality, the UNESCO Global Monitoring Report (UNESCO, 2005) is primarily concerned with quality in formal schools - while acknowledging that non-formal schools with teachers recruited from the community might be a response for areas where there is no school, rather than seeing this as perhaps desirable more generally. Moreover, the 2006 Report on literacy where alternatives are discussed focuses mainly on adult literacy, rather than alternatives for children (and youth).

The MDG has a narrower focus on formal primary schooling, with calculations of the cost for achieving this based only on those enrolled in these institutions (Bruns et al, 2003). In this vein, the EFA Fast Track Initiative (FTI), developed with the aim of ensuring that 
international agency support is forthcoming for the achievement of MDGs, focuses attention on formal schooling (recognising that this will mainly be government-provided, with some allowance for private provision). While it does not refer to NGOs specifically, non-formal education is mentioned with respect to vocational programmes, and the need to take account of the costs of these to ensure resources are available for universal primary completion to be achieved. This is an issue of concern with respect to recent attention to extending the FTI to fragile states, where much provision is via 'alternative' approaches of non-state providers particularly where states are seen as lacking legitimacy, and so would require that the FTI channels resources through alternative routes. This is not feasible under current arrangements, given the funds are managed and disbursed by the World Bank that has to provide support to governments.

In reviewing progress towards achieving the MDGs, the Millennium Task Force Report (Birdsall et al, 2005) focuses mainly on strategies aimed at getting children into formal, government schools (including demand-side strategies such as fee abolition, conditional cash transfers, school feeding, health programmes in schools, addressing girls' constraints, and supporting post-primary opportunities). There is passing reference to non-formal education for girls and women. The report does mention particular examples of non-formal education programmes aimed at minority language groups in Mexico, and child labourers in India, and alternative approaches for scheduled castes in India - thus reinforcing the exclusionary approach of non-formal education where it is considered good enough for the most vulnerable or marginalised - but not needed for those who can access the formal system.

Coombs and Ahmed's (1974) study marked a change in focus for the World Bank towards non-formal education, although probably only in rhetorical terms. In practice it never resulted in much focus being given in World Bank financial support towards non-formal education, with very limited attention to attempts calculate rates of return to non-formal education which would be a pre-requisite for their funding - not least because of the difficulties in doing so (Rose and Dyer, 2006). Most recently, the World Bank’s Education Strategy mentions nonformal education only once, with respect to 'non-formal education for young adults to provide them with a second-chance to acquire skills' in South Asia (World Bank, 1999: 36).

With respect to UN agencies, drawing on the quagmire of terminology, UNICEF (United Nations Children's Fund) has brought together the array into its definition of non-formal education:

A set of complementary programmes for the unreached or poorly served...an approach to education...leading to greater flexibility in organization and management of educational programmes with a decentralized structure and less authoritarian management style. It also promotes adaptation of programmes to needs and circumstances of learners, a learner-centred pedagogy, creative ways of mobilizing and using educational resources, community participation in planning and management of programmes, and learning content and methods related to the life and environment of learners... (UNICEF, 1993, cited in Mfum-Mensah, 2003: 663).

Furthermore, the International Institute for Educational Planning (IIEP) at UNESCO includes a strand of work on 'Alternative strategies of education and training for disadvantaged groups'. ${ }^{10}$

With respect to bi-lateral agencies, as noted, USAID's agenda is particularly concerned with complementary approaches with support being channelled directly to programmes run by NGOs and communities (Miller-Grandvaux et al, 2002). For the Japan International

\footnotetext{
${ }^{10}$ See http://www.unesco.org/iiep/eng/research/comproj/disadvantaged.htm
} 
Cooperation Agency (JICA), non-formal education is referred to in terms of education for youth and adults related to enhancing 'necessary life skills', but recognises that it has little experience in this area (JICA, 2002: 40). For Sida (Swedish International Development Cooperation Agency), 'short-duration, non-formal education cannot be a substitute for formal education, and it cannot be a sustainable solution to the problem of poverty' (Melin, 2001: 19). The report goes as far as to conclude that recent emphasis on non-formal education (as well as neglect of secondary and higher education) may cause harm to the development of education in developing countries, and accentuate education poverty, and human development poverty.

DFID’s Education Target Strategy Paper recognises that 'inclusion requires flexibility' and so governments may need 'cost-effective and imaginative alternatives to the formal system' to reach the marginalised (DFID, 2001: 18). In this respect, it mentions low-cost suitcase radios in Uganda, and non-formal, condensed programmes in India (which adopt the formal school curriculum). The document incorporates a range of the terminology as discussed in Section 2, noting 'Complementary or non-formal primary or pre-primary education programmes acting as alternative delivery structures or bridges into school provide important routes into education and valuable lessons for the formal system' (DFID, 2001: 22. Emphasis added). As such, the concern remains with formal education, and with 'para-formal' approaches intended to support this. Such approaches are also mentioned explicitly with reference to HIV/AIDS education. It also recognises the role that the non-state sector can play, although this is often neglected in national plans or seen as 'mopping up' those failed by government schools. The report suggests that the private sector, religious organisations and NGOs need to be seen more as a 'vibrant addition to the education sector, including a source of replicable innovation' (p25), while recognising the importance of these non-state providers working closely with governments if initiatives are to be effectively scaled-up. This raises questions of whether and how NGO innovation (where it occurs) can be maintained as they become more widespread, an issue which is of relevance to the more general debate surrounding NGO provision.

By contrast, the more recent 2005 DFID report on its commitment to girls' education is more narrowly focussed, with attention almost entirely on formal schooling. It recognises the challenges of channelling funds in fragile states - suggesting alternative ways of doing so, including through the World Bank, United Nations, European Commission or Regional Banks, as well as providing direct support to civil society and faith-based groups to help them to deliver basic services. Unlike the Education Target Strategy Paper there is no mention of non-formal education, alternative approaches, accelerated learning etc. Similarly, in the 2005 Girls' Education Strategy, the focus is on formal schooling, with recognition of the role that NGOs (for example, Save the Children-UK) play in fragile states. This changing emphasis in DFID papers reflects the more general shift in their focus of support from EFA to MDGs, with an associated shift towards formal primary schooling (Rose and Subrahmanian, 2005). 
Figure 3 Summary of international influences on non-formal, alternative and complementary approaches to education

1970s: attention to non-formal approaches

Basic needs approach

Concern of achieving UPE by 1980

Criticisms of formal schooling

1980s-'90s: swing back to formal, with 'alternatives'

Structural adjustment conditionalities resulting in a decline in resources towards state schooling

Non-formal seen as 'band aid' and second-best

2000s: emphasis on 'complementary' approaches

Governance agenda: education's role prioritised further in the context of emerging democracies with emphasis on state provision

Concern for achieving MDG/EFA by 2015

Complementarities between state and non-state approaches - search for alignment

\subsection{National policies and plans}

In countries such as India and Bangladesh, there is a long history of indigenous NGO provision of education (with BRAC non-formal provision dating from 1985 in Bangladesh with other forms evident before then, and dating from the $19^{\text {th }}$ century social reform movement in India) (Chowdhury and Rose, 2004; Nair, 2004). For other countries, including Ghana and others in sub-Saharan Africa, NGO provision is a more recent phenomenon, more closely associated with its promotion by some international aid agencies and international NGOs.

At the time of Coombs and Ahmed's (1974) study, few countries had included rural nonformal education programmes within their education and development strategies. This situation had not changed until very recently. Over the post-Dakar period, changing aid modalities, including basket funding associated with sector-wide approaches (SWAps) as well as moves towards direct budgetary support, has led to more involvement of non-state providers in policy dialogue. This has been further enhanced by the creation of umbrella associations to strengthen the voice of these providers in the policy process (Rose, 2007). As a result, as indicated below, national plans are beginning to pay more attention to alternative education programmes in recent years - no doubt reinforced by the fact that international agencies supporting SWAps which are funding these programmes are keen to ensure their recognition in plans. However, their recognition remains limited, and highly variable across countries.

According to a review by Caillods and Hallak (2004), seven of the 18 Poverty Reduction Strategy Papers (PRSPs) do not include reference to non-formal education for out-of-school children. In those where it is referred to, it is usually in relation to providing 'second-chance' opportunities for uneducated young people and dropouts (sometimes emphasising girls). In some cases, non-formal education might appear in different places of PRSPs, associated with particular training purposes - but there is often limited information on the costing of these programmes included in PRSPs.

India is unusual in having a focus on non-formal education within government plans over an extended period of time, with attention to programmes run by state governments. The nonformal education scheme was introduced in 1977-8 on a pilot basis (i.e. not long after Coombs 
and Ahmed's study), and has expanded in subsequent years, with a focus on primary schoolaged children who are unable to access the formal system. The focus was on school dropouts, for children from habitations without schools, working children and girls who could not attend whole day schools in 10 'backward' states, with more recent attention extending to other areas. The role of non-formal education, envisaged as closely related to formal education, is elaborated upon in the $6^{\text {th }}$ Five Year Plan 1980-1984 (Government of India, 1980), which notes 'The long range goal of educational planning is then to make available diverse networks of facilities and programmes for education, combining formal and non-formal modes of learning,' and 'Programmes for non-formal learning would be organised and oriented towards target groups and decentralised in regard to their contents, course duration, place and hours of learning and pattern of instructions. However, there would be a basic minimum package of inputs identified by the public educational authorities which would have correspondence to the formal system of education. In both formal and non-formal systems, the emphasis would be on the retention of students and effective delivery of services to children.'

The 7th Five Year Plan (Government of India, 1985) continues in this vein: 'Non-formal education would be the other important programme for the achievement of universalisation of elementary education as this can be useful to those who are not able or willing to attend fulltime schools. The number of children to be covered by the non-formal programme is reckoned to be of the order of 25 million. Non-formal education in the Seventh Plan will, therefore, have to be expanded at a fast pace and made acceptable with a variety of forms to suit the varying needs of the target groups. Non-formal system should be made flexible and appropriately linked to the formal system.' This plan recognises the need to train teachers for non-formal education, an issue that had not previously been given attention. Even so, the number of children intended to be catered for in the non-formal system remains small relative to the school-aged population as a whole of over 200 million children. By the $8^{\text {th }}$ Five Year Plan (Government of India, 1992) greater recognition of the involvement of 'voluntary' organisations in providing non-formal education is apparent, with NGO roles recognised for early childhood education and adult education, although still not referred to with respect to elementary education. The $9^{\text {th }}$ Five Year Plan (Government of India, 1997) marks a further shift in this regard (with non-formal education now appearing under a heading 'alternative education'), noting that 'It has been found by experience that NFE centres achieve more meaningful results when these are run by NGOs. Accordingly, the number of centres run by NGOs will be enhanced significantly. Where NGO participation is not forthcoming, State-run NFE centres will be established.'

While non-formal education has strong government support in India, an evaluation by the Government of India suggests quite different experiences compared with literature referred to in Section 3 which, as noted, mainly draws on studies by proponents of non-formal education (Figure 4). 


\section{Figure 4 Assessment of alternative provision within India's Sarva Shiksha Abhiyan}

- Insufficient involvement of the local community, the Village Education Committees (VECs) and the Panchayati Raj Institutions (PRIs).

- The absence of linkages for entry at different levels into formal schools and for tie-ups with the National Open School.

- Insufficient decentralisation of administrative and financial powers.

- Insufficient flexibility. NFE needs to recognise that different children's groups have different educational needs and modify itself accordingly.

- Lack of success with girls. The attendance at girls' centres and the number of women functionaries in the programme have been noticeably low.

- Delay in release of funds at all levels.

- Poor completion rates for the primary level by children studying in NFE centres. Very low transition rates to the formal system.

- The notion that the alternative system is inferior, second-rate and second-grade, both qualitatively and quantitatively.

- Low overall coverage of the scheme. It covers less than $10 \%$ of out of school children.

- Poor coordination of the work of Vas [village associations] with state governments.

Source: Government of India, Ministry of Human Resource Development, 2002.

This has led to the revision and renaming of non-formal education in India's education plan to 'Alternative and Innovative Education' (AIE) in 2000, building on the more successful experiences of Lok Jombish and the District Primary Education Programme (DPEP). In the development of this, the Sarva Shiksha Abhiyan (Universalisation of Elementary Education Programme) provides an outline of the 'ideological' debate surrounding alternative education, and its responses (Government of India, Ministry of Human Resource Development, 2002).

In many ways, India has led the field in non-formal education, often pre-empting debates in the academic literature with respect to changing terminology, role of the government etc. An issue that emerges from their most recent approach is the continuation of viewing it as an 'alternative'. In addition, despite the multitude of NGOs offering alternative provision in India (Nair, 2004), the focus is on government alternative initiatives with passing reference in the $10^{\text {th }}$ Five Year Plan to NGO support to community participation (Government of India, 2002).

By contrast, in Bangladesh where alternative service delivery by NGOs is relatively strong, this provision is hardly apparent in the government's Primary Education Development Programme (PEDPII) (Table 3). Furthermore, the recent Reaching out-of School Children programme supported by the World Bank has been developed outside of the framework of PEDPII. This raises an important question about what has contributed to approaches being more government-led and coordinated in India than Bangladesh. While the Bangladesh PRSP does make reference to non-formal education, this is mainly with respect to government initiatives in adult education. The PRSP notes, however, that to address the government's commitment to EFA and the MDGs, there is a need to support non-formal primary education, and that 'Sufficient resources should be available for this purpose. A regulatory framework and code of practice for involved NGOs should be established. A national policy for nonformal education should be adopted' (Government of People’s Republic of Bangladesh, 2005: 137). Here, non-formal education is explicitly referred to as 'second chance' primary education with the aim of linking these opportunities with skill development and formal 
education. ${ }^{11}$ There is also the intention of the Ministry of Education developing guidelines on the quality of education which are expected to apply to both government and NGO provision. Certainly, experiences in other countries are more akin to that of Bangladesh, although some are showing greater recognition of non-formal education provided by NGOs in more recent SWAps, as illustrated by recent experience in Ethiopia.

Table 3 Summary comparison of alternative provision in government plans

\begin{tabular}{|l|l|l|}
\hline India & Bangladesh & Ghana \\
\hline Since 1970s & Since mid-1980s & Since 1990s \\
State-led & $\begin{array}{l}\text { Grown out of locally-based } \\
\text { relief NGOs }\end{array}$ & $\begin{array}{l}\text { Donor-supported BRAC model } \\
\text { Included in government plans }\end{array}$ \\
$\begin{array}{l}\text { Integral to government plans } \\
\text { SSA (Sarva Shiksha Abhiyan) } \\
\text { Education }\end{array}$ & $\begin{array}{l}\text { Autonomous from government } \\
\text { plans }\end{array}$ & School for Life programme \\
& $\begin{array}{l}\text { BRAC and other large NGOs - } \\
\text { sub-contracting to smaller } \\
\text { NGOs } \\
\text { Reaching out of School Children }\end{array}$ & \\
\hline
\end{tabular}

Ethiopia's experience of alternative service delivery by NGOs becoming incorporated into national planning is illustrative of experience of other sub-Saharan African countries. One of the objectives of the 1994 Ethiopian Education and Training Policy is to make available special and non-formal education in line with the needs and capability of the country; and to promote relevant and appropriate education training through formal and non formal programmes. The first Ethiopian Education Sector Development Programme (ESDPI) indicated the intention that non-formal education would provide a second chance to school dropouts and those youths and adults who have never had the opportunity to attend schools, and that children out-of-school would benefit from an opportunity to become literate through non-formal education. However, ESDPI did not give much attention to this area. By contrast, alternative basic education programmes (particularly those offered by NGOs) are considered to play an important role in ESDPII as a means to achieve UPE by 2015. Non-formal education models are proposed within the programme as an alternative to school-based primary education for out-of-school children and for very sparsely populated and remote communities, with options for graduates of these programs to join the regular schools.

These programmes are considered to be of particular benefit to girls by locating learning centres closer to homes and recruiting female instructors where possible. They aim to develop curriculum and learning materials that are more responsive to special needs of girls, encouraging advocacy and social mobilisation involving the use of communication media. They also target pastoralists by providing a more flexible and relevant education. Non-formal systems in operation offer a three year cycle which is considered equivalent to the four year formal system, in line with accelerated learning 'complementary' models referred to in Section 3. Attempts are made to ensure that the NGO non-formal system links into the second cycle of government formal primary schooling (along the lines of complementary approaches discussed earlier in the paper), and some regions have begun to accept those who complete the three-year cycle into grade 5 of formal schools.

\footnotetext{
${ }^{11}$ Interestingly, the Bangladesh PRSP uses language of 'long-route' and 'short-route' accountability (p174-175), as developed in the 2004 World Bank World Development Report. See Section 2.
} 
Coverage of alternative basic education in Ethiopia remains low, constituting just 2.5 percent of the school-aged population. Even so, although ESDPII places emphasis on alternative basic education to reach out-of-school children, it still only intends to expand the programme to 500,000 children. Given that the school-aged population will also increase over the period, the proportion of children served by these programmes will hardly change (to 2.6 percent). Despite the attention given in ESDPII to non-formal education to address girls and other children out of school who would be assisted by a more flexible system, adult and non-formal education only receive 1.1 percent of the education budget. No financial resources are included in the budget for curriculum development, also implying that NGOs are expected to play a key role in this. Furthermore, the budget for these programmes includes just 30,000 Birr per annum for teacher salaries (where average primary teacher salaries are 7,000 Birr per annum) (FDRE 2002).

This raises an issue of concern, namely that considerable attention is placed on alternative basic education to reach out-of-school children in ESDPII, but in reality coverage of these programmes is extremely low and is likely to remain so. The opportunities for alternative basic education to expand sufficiently to reach the vast number of children who remain out of school is, therefore, dependent on NGOs, who currently are the main providers of alternative basic education, significantly increasing their involvement in this area although there is no evidence that NGOs are willing or able to do so. It is apparent that an important reason for the promotion of the role of NGOs is related to the resources that international NGOs are expected to provide, while recognising the implications this has for the need to strengthen government/NGO partnerships (Figure 5).

\section{Figure 5: Recognition of alternative providers in Ethiopia's Education Sector Development Plan}

To implement the program at a possible lower cost, the community and NGOs shall be encouraged to stand by the side of the government.... A stronger and wider role for nonformal education and other alternatives for expansion of primary education shall be implemented. (p 21, 22).

Government/NGO partnership shall be strengthened to develop and implement complementary basic education initiatives in the regions... Alternative modes of delivery of education will be expanded and strengthened besides the formal schooling for children that could not join schools because of age. However, age will not be considered in woredas [districts] or schools where the overall GER (gross enrolment ratio) and girls' enrolment are very low. (p 24).

It is commonly accepted that non-formal education can be a shortcut and cost effective alternative way of providing basic education. Therefore, REBs [Regional Education Bureaus] will use this opportunity to the maximum and give due attention to the expansion of the nonformal education programs with the full participation and contribution from communities and NGOs. (p 31).

As coordination at the various levels is particularly important, forums will be created in which the government and NGOs partnership will be strengthened for a common and shared aim of giving education for all. (p 36).

Source: Federal Democratic Republic of Ethiopia (FDRE), 2002

The 2003-2015 Education Strategic Plan in Ghana similarly indicates recognition of 'complementary and alternative education programmes' for the 'disadvantaged', noting the 
need for evaluation of these programmes. This is the first policy to acknowledge and encourage complementary education (Hartwell, 2004). Emphasis within the Plan is, however, placed on the formal system - with the aim to 'reach and integrate excluded children (out-ofschool, hard-to-reach, truants) intra-cycle dropouts and adolescent mothers within the formal system where possible' (Government of Ghana, 2003: 21), with the intention of integrating complementary and formal schools. The Plan does not discuss explicitly the role of NGOs in supporting the alternative/complementary provision; nor the challenges around integration given the role of different providers. Marking a more recent shift in this respect, the 2006 Education Sector Performance Report provides some explanations for this omission, raising difficulties of coordinating NGO activities within the sector-wide approach, noting that 'On a number of occasions, the activities being undertaken [by NGOs reporting their activities] were very similar to those being undertaken or piloted at central Ministry level. The absence of communication between the Ministry of Education and NGOs is therefore leading to inefficiencies on two fronts -

- Programmes being undertaken by NGOs will be discarded once the Ministry of Education activity is introduced, or

- Successful programmes being piloted by NGOs may not come to the attention of MOESS, and, therefore, due to a lack of resources on the part of the NGO, such programmes will not be replicated across the country.' (MOESS Ghana, 2006: 100).

This gives rise to a suggestion in the report of involving NGOs more actively in policy discussions, with an NGO desk to be set up in the Ministry of Education to coordinate NGO activities. The NGO desk would coordinate with District/Regional Education offices since this is the level at which NGOs often operate. It further suggests using larger NGOs to collect expenditure data for NGO operations (given the large numbers of NGOs, the Ministry itself does not have the capacity to do this). This aims to ensure that the data are included within information on external sources of funding, allowing the Ministry to plan activities in a more strategic manner. The invisibility of NGOs in the Plan is, therefore, seen as the responsibility of NGOs themselves, rather than the reluctance of government to recognise them. Experience from the Campaign for Popular Education's (CAMPE) compilation of an NGO directory in Bangladesh (CAMPE, 2004), and BRAC's relationship with smaller NGOs, could be instructive in this regard (Chowdhury and Rose, 2004). In both cases, however, questions arise of who NGOs are accountable to, as the Ministry does not have systems in place to monitor their activities, and does not have the capacity to do so. In addition, despite the availability of data on NGO activities in Bangladesh, they do not appear to be used by government for sector-wide planning in the way envisaged in Ghana.

In line with education plans in other countries, complementary/ alternative approaches in the 2003-2015 Ghana Education Sector Plan are discussed primarily with respect to access. While increasing attention is placed on quality within more recent plans, it refers only to quality within the formal system - with no explicit signs of an intention that lessons from innovative approaches from the complementary/ alternative approaches are drawn upon. As such, integration of approaches does not yet appear evident.

While in the plan itself alternative/complementary approaches are included, 'non-formal' education is not referred to. However the budget includes a line for non-formal education, but not for alternative/complementary approaches. Since the Non-formal Education Department is primarily responsible for the development and delivery of education programmes for out-ofschool youth and adults, it would appear that the budget relates to this rather than alternative/complementary approaches for children. In any case, the amount allocated is a mere 2.7 percent of primary school allocation, or 1.1 percent of the total education budget for 
2003, with the proportion of the total budget projected to stay more or less constant up until 2015. This suggests that there is neither a plan to integrate all those involved in the complementary system within formal schools and eliminate NGO provision over the period, nor to expand the alternative/ complementary approaches.

The lack of budget allocated to support the commitment to alternative/complementary approaches within the plan suggests that programmes such as School for Life will continue to be reliant on external funding sources, including DANIDA (Danish International Development Agency) and USAID, with concerns of the sustainability of such an approach. As Hartwell (2004: 11) suggests: 'The question remains whether the government only sees such programs as acceptable as long as they are financed outside the public budget. If there were a decline in external funding, would that mean a contraction or collapse of the program? The policy issue is whether pubic funds can be used to support complementary education initiatives that demonstrate effectiveness and whether the government can manage such a grant program so as to maintain, if not enhance, that effectiveness'. The responsibility for this should not be limited to government: 'nongovernmental actors need to... think critically about how their actions could enhance and extend public sector capacity. They also need to think more broadly about their role within developing countries and no longer define their mission as filling the space left vacant by government, if provision of schooling is going to be progressively incorporated into the public education system' (DeStephano et al, 2005: 16). In contrast to the more recent developments in education plans in Ghana, the Ghana PRSP makes very limited reference to alternative or complementary approaches, or to the role of NGOs in education (Republic of Ghana, 2005).

As with Ghana and Ethiopia, experience from other sub-Saharan African countries also indicates that while SWAps developed in the 1990s more-or-less ignored non-government alternatives, growing attention has been paid since 2000 to non-formal alternative/complementary approaches within their plans as a means to support government moves towards UPE. In Tanzania, for example, the 2002 Primary Education and Development Plan incorporated the Complementary Basic Education and Training programme (COBET), supported by UNICEF, for three million children estimated to be out of school (Hoppers, 2006).

Despite evidence of increasing attention now being given in some countries to including NGOs as alternative service delivery providers within plans, it remains the case that government resources prioritise formal schooling - with the alternatives seen to be the responsibility of other providers. For some, this raises an unresolved challenge:

'The challenge is finding ways to incorporate these [complementary] strategies into the sector investment programs that draw the bulk of government and external financing and attention' (DeStephano et al, 2005: 16). 


\section{Experience of access in alternative and complementary education programmes}

\subsection{Patterns in access to alternative education programmes}

Patterns of access in alternative education programmes are extremely difficult to assess as data are not generally collected on these in a systematic way within countries, and household data sets do not usually include information on this unless it is the explicit focus (such as CAMPE's surveys in Bangladesh - see, for example, CAMPE, 1999; 2000). The Young Lives Project which aims to collect data on the changing nature of child poverty in Ethiopia, India, Peru, and Vietnam includes questions in its survey instruments on schooling and adult literacy programmes, but not on non-formal education programmes for children and youth. Demographic and Health Study datasets and UNICEF's Multiple Indicator Cluster Surveys (MICS) do not systematically include information on non-formal alternative forms of provision. ${ }^{12}$ Information on access to individual programmes may be available from internal programme documents and evaluation reports, but these are not collated to provide a national picture. Furthermore, NGO programmes in some countries are not normally expected to register with ministries of education so they do not have information on this directly (Rose, 2007).

An attempt to collate data on trends in access to particular programmes is provided by USAID's EQUIP2 programme. This has undertaken a survey of complementary education programmes in 39 Sub-Saharan African countries. It has found 154 of such programmes, reaching a total of 3.5 million children. In Mali and Togo, for example, the programmes reach up to 10 percent of children enrolled at the primary level, while they account for the majority of primary school access in Somalia.

Based on a more detailed analysis of particular programmes across eight countries, USAID studies indicate that access and completion is systematically better compared with those in the formal government system. For example, completion rates in Ghana's School for Life programme is 91 percent, compared with 59 percent in government schools. Similarly, in Bangladesh, figures are 94 percent and 67 percent, respectively (DeStefano et al, 2006). While both programmes are intended to be complementary ones offering opportunities to join the formal system there is varied experience of opportunities of children to do so. Two-thirds of those enrolled in Ghana's School for Life programme have been able to join the formal school system. The reason for not joining the formal system is mainly due to lack of availability of a school in the vicinity (Akyeampong, 2004).

Evidence from the USAID reviews, as well as other studies (see Rose, 2007 for a review), suggests that these students can get access to an education that enables better quality learning compared with government schools. However, despite the gaps that these programmes appear to fill, concern remains that those living in extreme poverty, or suffering most acute forms of vulnerability, continue to be excluded. Moreover, some evidence suggests that these alternatives/ complementary programmes are more easily accessed by those who have already had some successful experience of education (Carron and Carr-Hill, 1991, cited in Hoppers, 2006). Moreover, even though non-formal education programmes offer educational opportunities that some children would otherwise not have, the differential experiences and possibilities offered by these could perpetuate disadvantage - with the danger that they could

\footnotetext{
12 The India MICS Report does not include any mention of non-formal, alternative or complementary provision. The Afghanistan report notes that there are very few formal school opportunities in East Afghanistan, and so 'any type' of schooling has been accepted. This includes a 'non-standard' type, although it is not clear what this is referring to in the report, and covers less than one percent of primary school-aged children.
} 
exacerbate social exclusion. One area that has been neglected in terms of understanding the benefits of these programmes relates to the opportunities that they offer in terms of changing livelihood opportunities, access to different kinds of employment and/or access to higher levels of education (see Rose and Dyer, 2006 for a review on education and chronic poverty, which highlights the lack of research on the post-education implications of education programmes).

While some adult education programmes adapt to be of relevance to the occupations of those involved in the programmes (such as agricultural extension services), the intended outcomes of alternative programmes for children and youth may be less tangible - for some, the programmes might be aimed at re-integrating them into the formal system (including gaining access to secondary and higher levels of education), for others it might be aimed at giving them basic literacy and numeracy skills; for others it can be a preventative measure to keep them away from exploitative child labour. Gaining a clearer understanding of this is crucial for understanding what the underserved are getting access to - and whether this can contribute to social mobility and poverty reduction. These concerns warrant further investigation.

\subsection{Cost-effectiveness of alternative education service delivery programmes}

Assessments of cost-effectiveness of alternative education service delivery programmes continue to be plagued by limited data availability. Estimating their costs is further complicated by the type of information required for a full evaluation. As Coombs and Ahmed (1974) note, this requires information on financial costs, as well as opportunity costs (including costs of 'borrowed' facilities, volunteer help - including of teachers, contributed materials and services). Furthermore, the costs of monitoring and supervision of teachers often a key benefit of the programmes and one that can be highly variable across programmes, are often not readily available. ${ }^{13}$ Similarly, benefits ought to include direct benefits (as assessed by improvements in incremental production and income) as well as indirect and noneconomic benefits.

A recent attempt as part of USAID's EQUIP2 programme at comparing costs of complementary programmes with formal schooling also recognises methodological and data challenges. With caveats, the programme finds that the complementary education models are more cost-effective in terms of the amount of completion and learning for the resources spent, even though in some (for example, Ghana and Mali) the annual unit costs are higher than government schools - no doubt partly because the increased costs required in educating those who are most difficult to reach (Table 4).

\footnotetext{
${ }^{13}$ See Ilon (2002) for a comprehensive attempt at calculating these costs in Uganda.
} 
Table 4 Comparing costs of schooling between complementary education programmes and government schools (\$)

\begin{tabular}{|l|c|c|c|c|c|c|}
\hline & \multicolumn{3}{|c|}{ Annual cost per pupil } & \multicolumn{3}{c|}{ Cost per completer } \\
\hline & Compl. & Govt. & Compl./Govt. & Compl. & Govt. & Compl./Govt. \\
\hline $\begin{array}{l}\text { Afghanistan- } \\
\text { COPE }\end{array}$ & 38 & 31 & 1.23 & 453 & 485 & 1.07 \\
\hline $\begin{array}{l}\text { Afghanistan- } \\
\text { IRC }\end{array}$ & 18 & 31 & 0.58 & 132 & 485 & 3.67 \\
\hline $\begin{array}{l}\text { Bangladesh- } \\
\text { BRAC }\end{array}$ & 20 & 29 & 0.69 & 84 & 246 & 2.93 \\
\hline $\begin{array}{l}\text { Egypt- } \\
\text { UNICEF }\end{array}$ & 114 & 164 & 0.70 & 620 & 911 & 1.47 \\
\hline $\begin{array}{l}\text { Ghana-School } \\
\text { for Life }\end{array}$ & 39 & 27 & 1.44 & 43 & 135 & 3.14 \\
\hline $\begin{array}{l}\text { Honduras- } \\
\text { Educatodos }\end{array}$ & 40 & 102 & 0.39 & 197 & 803 & 4.08 \\
\hline $\begin{array}{l}\text { Mali- } \\
\text { SC-US }\end{array}$ & 47 & 30 & 1.57 & 197 & 803 & 4.08 \\
\hline $\begin{array}{l}\text { Zambia- } \\
\text { Community } \\
\text { Schools }\end{array}$ & 39 & 67 & 0.58 & 376 & 655 & 1.74 \\
\hline
\end{tabular}

Note: given the way in which information is available for different countries, data in the table are comparable within countries, but not across countries

Source: DeStefano et al, 2006.

A question arises as to whether these programmes can be extended to others currently excluded from education in these countries, and whether the costs of doing so would be sustainable given an important reason for the lower costs (where they exist) is related to lower pay of 'voluntary' teachers, supported by community contributions. For example, in Bangladesh estimates indicate that teachers in government schools receive around $\$ 70$ per month, compared with $\$ 9$ for those working in NGO centres (Groundwork Inc., 2002). It is highly unlikely that a mass state system could rely on para-teachers working on a semivoluntary basis, implying that costs of complementary approaches would increase dramatically if provision is scaled-up and/or integrated within state provision 


\section{Scaling-up, Coordinating and Mainstreaming NGO Provision for Sustainability}

As the above sections indicate, alternative or complementary service delivery by NGOs aims to provide innovative, flexible approaches which are responsive to those being served. This gives rise to questions of why these continue to be viewed as an alternative, particularly since the intention of the innovative NGO provision is to suggest lessons for state schooling. These generally small-scale programmes raise further challenges for the state as their efforts are often fragmented across different agencies. Concerns are frequently raised that pilot projects do not move beyond a pilot, and disappear when external funding finishes. Coombs and Ahmed's statement that 'All over the developing world there are graveyards of abortive pilot projects long since forgotten by those who first inspired them (who are often too busy with the next crop of pilots to conduct revealing post-mortems on their earlier attempts; hence errors are often repeated)' (Coombs and Ahmed, 1974: 181) is as true today - and where evaluations have been undertaken, these are often undertaken internally and not made publicly available, giving rise to questions of how accountability to those paying for the programmes is ensured. How then can these approaches be coordinated, and 'scaled-up', and what experience is there of this occurring?

\subsection{Scaling-up or mainstreaming 'alternative’' complementary provision}

It is often stated that the intention is to 'scale up' innovative approaches offered by 'alternative' or complementary provision. International NGOs themselves usually do not see their role as substitutes for the state (Archer, 1994) or as service providers in the long-term. Where they are involved in provision, they design their programmes with an exit strategy in principle - although experience indicates that this is more difficult to achieve in practice.

However, this gives rise to questions and concerns where the success of a programme is based on the localised scale at which it has been operating, while the state is seen as having the legitimate role for large scale provision of basic education. As such, the aim is more appropriately viewed as building on innovative approaches arising from adaptations in NGO provision into longer-term, sustainable planning through the state, rather than scaling up NGO provision itself. This relates to Thompson's (2001: 24-25) use of the concept of 'mainstreaming', referring to the inclusion of non-formal approaches into the mainstream education system. In this context, he provides different definitions of mainstreaming as follows - moving from narrower, less challenging understandings to more radical approaches:

- 'Mainstreaming as official recognition of alternative approaches by non-state providers (this could include their inclusion in legal frameworks for basic education, and inclusion in education plans and official education statistics, requiring their registration with relevant education authorities which would take responsibility for their oversight);

- Mainstreaming as integration (where non-formal and formal education are integrated into one system with routes of access between them, based on a system of equivalency - thus related to para-formal approaches. This could involve non-formal approaches adopting aspects of the formal curriculum, and formal approaches incorporating non-formal attributes into its structure etc.);

- Mainstreaming as system transformation (redesign of basic education, adapting to the successful innovative approaches learnt from alternative systems)' (Thompson, 2001: 2425). 
Thus, rather than increasing the size of innovative provision itself, scaling-up through mainstreaming implies ensuring the coordination of alternative approaches, and that they are integrated within a national system-wide planning approach.

In this respect, Samoff and Sebatane (2001) note that successful scaling up should aim to scale up the conditions that permitted the initial reform, based on the generation of widespread and locally-rooted demand for it (akin to mainstreaming as system transformation), rather than attempting to replicate specific elements of reform, as is often the case. They provide a useful overview of experiences of scaling-up education reforms in subSaharan Africa, which often relate to those provided by NGOs as innovative pilots, concluding that there are very few successful examples. This evidence suggests that the conditions that can support scaling up include the importance of leadership, sustained local involvement, careful planning for scaling-up from the outset, and availability of information systems.

This then relates to issues of state will and capacity which, by definition, is lacking in fragile states. It raises particular challenges for scaling-up through mainstreaming - where there is not already an established state mainstream, or this has been destroyed. Recent innovative experience is evident in the 'fragile state' of Afghanistan. This example is of particular interest as Afghanistan moved from being seen as in a state of 'arrested development' by donors, and so only supported on the margins (with the International Rescue Committee IRC - being the only US-based NGO involved in the country, for example) to the 'early recovery' phase - resulting in the involvement of a multitude of donors and NGOs, creating both opportunities in terms of resources, but also challenges with respect to service delivery fragmentation and the need for donor and NGO harmonisation. As a result, home-based schools initially established through spontaneous initiatives of women who wanted to ensure girls received an education under the Taliban, which then became supported by INGOs (international non-governmental organisations), have become mainstreamed into state systems. In one case, the students and teachers remain in place, and the home-based school simply changes status to become an officially recognized and supported government school. In the other case, the home-based school ceases to operate and the students - and when possible the teachers - transfer to a government school. Sometimes the students transferring into a government school are joined by additional students coming from other nearby areas, as well as new students entering school for the first time. IRC is working on a third scenario that would cluster several nearby home-based schools to create one new government school. Since the home-based schools comply with Ministry of Education policies and curricula, a smooth transition between home-based schools and the formal, government system is possible in a situation where local demand for this has increased. As a result, girls' primary enrolment increased dramatically, from just three percent to 30 percent within a year. Furthermore, by framing home-based schools within the policy parameters and objectives of the government, IRC and other NGOs are helping strengthen the government system as opposed to competing with it. These schools promote and raise the profile of education at the community level, increasing demand for government schools (Kirk and Winthrop, nd).

The integration of home-based schools has been possible as the capacity of the Ministry of Education has been built, and it does not see these schools as competing with its own plans. This was only possible once the government was able to establish itself and gain confidence in determining its own priorities, allowing space for developing relationships between NGO and state service delivery (Rose and Greeley, 2006). 


\subsection{Government-NGO coordination}

Where scaling-up is related to integrating NGO provision into a state-led system, there is a need for coordination with the state which continues to assume overall responsibility for service delivery. Coordination can take the form of policy dialogue, contracting, facilitation, and registration and regulation - each of which are inter-related (Rose, 2007). As Section 4 indicates, alternative provision and providers in education plans has become more visible in recent years, in part due to greater involvement of providers in policy dialogue (even though 'real' on-going dialogue remains less common - Rose, 2007). There is extremely limited experience of facilitation of NGO alternative provision, given that governments often view this as a way of expanding access through obtaining alternative sources of funding via NGOs and community contributions. There is, therefore, very little incentive for NGOs to register or coordinate more generally with governments (other than where they have to do so in order to obtain foreign funds), even though their existence might be motivated by working with government to build on lessons from their innovations.

Akyeampong (2004) notes, in the context of the School for Life programme in Northern Ghana, that there is no such thing as 'independent self-help efforts', as self-help (or community participation, as it is termed in other contexts) has to be located within a broader institutional framework. This includes ensuring that forms of support are forthcoming when NGO funding is no longer available. In addition, systems for allowing students to transfer between programmes to the formal system are needed. Although this has been relatively successful in the School for Life programme and also for BRAC, it has occurred through building of relationships which rely on individuals rather than systems - and is unlikely to benefit other programmes that operate at a smaller scale. It also means that there are no mechanisms for sharing experiences, developing local capacity to sustain the programmes etc. As highlighted from Malawi's experience, without foresight to developing constructive relationships, innovative experiences can disappear when funding dries up, and community support is not sustained (Kadzamira and Rose, 2004). In the case of Ghana, Akyeampong (2004) suggests that one possible approach is to develop relationships through decentralised systems, enabling alternative routes to basic education to be sustained through 'dovetailing' into the formal system, and so influencing policies that shape how money is to be spent. However, this continues to raise a challenge for governments which would need to loosen centralised control over the education system, but are often reluctant to do so (Rose, 2005).

In order to facilitate coordination, some countries have a Department for Non-formal Education (for example, Botswana - although this deals mainly with adult education). Such structures are not always successful, however, as experience from Bangladesh illustrates. In the 1980s, a Directorate of Non-formal Education was established, which took responsibility for contracting NGOs involved in service delivery, the funding for which primarily was provided by international donors. Initially, some well-resourced NGOs felt this arrangement would be beneficial, both because it would enable them to influence policy from within, and also to have access to alternative sources of funding (Miwa, 2003). However, difficulties in contractual arrangements, including inefficient and untransparent procedures, tended to stifle innovation and reduce NGO flexibility and responsiveness to local needs. Some NGOs also felt uncomfortable with competitive bidding as it was felt that this encouraged a business approach to education (Cummings et al., 2004). In addition, the process of selection of NGOs resulted in the contracting of some 'briefcase' NGOs, established by former civil servants with the aim of obtaining funds rather than for the purpose of providing education (Miwa, 2003). The Department was disbanded, and a recent evaluation indicates that donors and NGOs are not keen on re-establishing contracting through this type of route (Cummings et al., 2004). The recent PRSP indicates the intention to set up a new Department. This could be 
appropriate for coordinating NGO activities, ensuring that the Ministry of Education is aware of them, and integrating them within education plans, without playing such an interventionist role with respect to contracting.

As noted, governments have often not taken over innovative 'pilots' of NGOs but rather allow them to disappear with donor funding. One reason for this is that governments sometimes are not sufficiently aware of their existence - either because they do not formally recognise them, or NGOs choose not to liaise with government. Another is that the non-government provision can create tensions with the standards set for formal schools, in particular with respect to the recruitment, training and pay of teachers. Perhaps often a key reason is the difficulties governments face in meeting the additional costs - given the marginal costs of reaching the excluded are likely to be significantly higher than to those easier to reach, particularly where government taking over of these schools would require the government to pay teachers at the civil service rate, rather than lower community-supported rate.

Furthermore, as experience from Save the Children-US Village-based Schools Malawi (funded by USAID) indicates, government take-over can undermine flexibility as more formal procedures are expected to be followed. Most of the innovations of the programme were a departure from the Ministry of Education's norms and standards, raising fears by government that if NGOs were given a free rein, it would lose control over the education system with recruitment of teachers a particular area of contention (Kadzamira and Rose, 2004). As with other programmes following the BRAC model, in contrast to the centralised recruitment and deployment of teachers in government schools, teachers were recruited locally by community members with particular attention to the recruitment of female teachers to serve as role models for girls. Since there were insufficient qualified teachers available locally, they often did not meet government standards. Even so, the schools performed better on average than their government counterparts, in part because they were able to retain teachers, and so had smaller classes on average than government schools (Hyde et al, 1996). Government insistence on standards, particularly related to teacher qualifications, led to the abandonment of the innovations in the programme when the government was expected to take over, and so did not extend beyond a pilot. While some of the difficulties encountered could have been overcome by closer attention to agreeing on arrangements for take-over at the design stage, some attempts were made in this regard in this case. An alternative way to support these schools proposed by USAID would be to provide block grants or grant-in-aid so that the programmes can maintain autonomy over recruitment procedures etc. (DeStefano et al, 2006).

In some cases, those involved in the NGO innovations are the same people as (previously) responsible for formal provision. For example, Akyeampong (2004) notes, most School for Life officers are former employees of the Government Education Service, and many worked in the district education offices in the North of Ghana. This gives rise to a question of why they are able to accept flexible, responsive approaches to education while working for School for Life but not able to do so in the government job - was this due to lack of resources, bureaucratic constraints, changing attitudes through training, or for other reasons? Why is leadership possible in one but not the other? Responses to this could help to address how government provision itself might become more responsive.

Collaboration between NGO providers and government requires recognition of the existence of alternative providers. Such recognition is most often evident where the providers have to register. A first step to recognition is inclusion of their provision within education plans (see Section 4). As the EQUIP2 studies indicate, there are a number of ways in which government collaborates with and supports the complementary programmes, with variations of the extent of interaction across countries: 
- Possibility of students transferring from alternative to government system (all case studies)

- Programme designed with government (Egypt, Honduras)

- Curriculum developed with government (Egypt)

- Local education authorities provide some oversight and support (Mali)

- NGO facilitates capacity building activities for MOE (Ministry of Education) staff and teachers (Afghanistan-COPE (Community Supported Primary Education))

- Conversion of community schools into government schools (Afghanistan-COPE/IRC)

- Financial support through grants-in-aid/payment of teacher salaries (Egypt, Honduras, Mali, Zambia)

- Government testing of students (Ghana)

- Government provision of distance learning for locally-recruited teachers (Ghana)

- Government Secretariat to oversee community schools (Zambia, Bangladesh - under creation).

As these examples indicate, most collaboration and support is through government facilitation of the alternative providers. Interestingly, the BRAC programme in Bangladesh that is generally heralded as being particularly successful appears to be more autonomous from government than many of the other programmes - perhaps because it has the capacity to sustain itself.

There are examples where support also occurs in the other direction (for example COPE facilitating capacity development activities of MOE staff and teachers in Afghanistan). This bi-directional support is particularly key to ensure sustainable solutions, both to ensure that lessons from innovations are applied to government systems, and to build the capacity to allow government to implement these when it is appropriate to do so. The collaborative arrangement between UNICEF and the Ministry of Education in Egypt was seen as a 'seed bed' for reform, rather than a scalable operation, with the aim of expanding impact through applying lessons to other areas of service delivery, rather than spreading the project itself (De Stefano et al, 2006). 


\section{Conclusions and Proposals for Further Research}

Even where states are unable to provide basic schooling to all their population, they commonly see this as their ultimate aim, with democratic processes placing pressure on them to do so by the electorate. This is evident by the high profile fee abolition has played in election campaigns. Furthermore, NGOs themselves view mass education primarily as a state responsibility, and often do not seek to scale-up their own provision. However, many countries rely on NGOs to reach those who have most difficulties in gaining access to the formal education system implying that, rather than being the provider of last resort, by default at least, the state is provider for the masses but not the marginalised.

The paper highlights the importance of looking beyond access to formal schooling, the focus of the education MDG. Rather, it shows that there is not one type of access to basic education, with different forms of access available to marginalised children both in terms of who is providing the education and the type of education provided. Official statistics may categorise those gaining access to these alternatives as being in Zone 1 (as being denied any access), implying that estimates for out-of-school children in Zone 1 may be exaggerated. However, questions remain of whether alternative forms of access are 'equal' (even if different) to formal education in terms of the opportunities they give rise to, or whether the ultimate goal to gain access to formal education remains.

As the paper has shown, despite continued attention to non-formal, alternative and complementary approaches since Coombs and Ahmed's study, very limited critical, systematic analysis has been undertaken to assess the implications of such programmes particularly those focusing on children and youth. Where analysis of programmes does exist, these are most often undertaken as part of an internal evaluation process, in order to feedback into the programme itself, and to encourage further donor funding to support the programmes. These assessments do not take account sufficiently of the economic and social environment in which they are located (Rose and Greeley, 2006; Hoppers, 2006). There is extremely limited evidence available of the returns to gaining access to NGO programmes, with concern that they may exacerbate different forms of exclusion in the longer term where social mobility is not possible if further education or improved livelihood opportunities are not available. Moreover, further work is needed in order to assess whether the programmes are indeed reaching the most marginalised as intended. In order to assess the validity of claims of community-based decision-making and pedagogical innovation of the programmes, evidencebased research is required to gain an enhanced understanding of what children are gaining access to.

In order to fill these research gaps, it is therefore appropriate to do a stock-take of alternative and complementary education programmes 30 years on from Coombs and Ahmed's (1974) study, in the light of changing development targets and priorities - focusing this time on those aimed at reaching children and youth, rather than adults. This is particularly timely given recent moves towards aiming for convergence between alternatives and formal state systems, through identifying equivalency mechanisms which require different forms of interaction between NGOs and governments. As such a study of these issues should focus on multiple providers within a system-wide approach, rather than 'alternatives' or 'complements'. Such a study would include a critical analysis of:

- The coverage of different forms of provision within countries, particularly those areas where access to formal education is most limited.

- Demand for and supply of different forms of provision in such contexts, to explore who continues to be excluded from education, and how providers would need to be adapted further for them to gain access. 
- The extent to which programmes achieve their objectives, including in terms of community-based decision-making and pedagogical innovation; and the implications of this for access.

- A comparison of costs of different forms of provision, taking account of sustainability and scale.

- Future education and livelihood opportunities available to those gaining access to NGO programmes, compared with those in state schooling and those who do not gain access to any form of education

- Ways in which governments and NGOs do and can interact to ensure different forms of provision offer sustainable solutions for scaling-up access to those most marginalised from state provision.

The research approach would involve:

- Local mapping and surveys of households, communities, and education providers to assess who gets access to what; who is excluded and why; and the costs and scale of different forms of provision

- Tracer surveys and life histories of graduates from NGO programmes to explore possibilities they have had of joining the formal education system (and staying in), and the livelihood opportunities that access to NGO provision has permitted

- Case studies of selected NGO programmes to assess experiences of collaboration for integrating, mainstreaming and scaling up provision within state-led system-wide planning, and the obstacles to this.

As the paper has highlighted, there are some high profile programmes from which positive experiences can be identified, such as School for Life in Ghana and BRAC in Bangladesh. Within the contexts in which these are working, there are also smaller programmes likely to face different types of challenges with respect to coordination and harmonisation with the formal system. It would, therefore, be of interest to map the range of programmes available in countries such as Bangladesh, Ghana and India where NGO provision is relied upon to reach excluded children (either explicitly in policy as in Ghana and India, or implicitly as in Bangladesh), and explore the particular challenges different types of programmes face. Moreover, as noted, some countries (particularly fragile states) are reliant on 'alternative' approaches - where these are actually the convention as a mass state system does not exist. If EFA targets and MDGs are to be achieved by 2015 in terms of ensuring all children globally have access to a basic education, this would require further analysis of how education services can reach children in such contexts, while ensuring sustainability of provision by supporting the strengthening of state capacity and will in the longer term. 


\section{References}

Akyeampong, K. (2004) 'Complementary Education in Northern Ghana: A Case Study of Aid for Self-Reliance?' Journal of International Co-operation in Education, Hiroshima University Centre for the Study of International Cooperation in Education, Japan.

Archer, D. (1994) 'The changing roles of non-governmental organizations in the field of education (in the context of changing relationships with the state),' International Journal of Educational Development 14(3): 223-232.

Balwanz, D., A. Schuh Moore and J. DeStefano (2006) Complementary Education Programs in ADEA Countries. ADEA. Available from: http://www.adeanet.org/biennial2006/Ecoles/vo/Word/B5_1+_balwanz_en.doc [Accessed 28 August 2006].

Bano, M. (2006) 'Non-profit education providers vis-à-vis the private sector: comparative analysis of NGOs and Traditional Voluntary Organisations in Pakistan,' Compare [in press].

Birdsall, N., R. Levine, A. Ibrahim (2005) Toward Universal Primary Education: Investments, Incentives and Institutions. London: Earthscan.

Bowles, S. and H. Gintis (1976) Schooling in Capitalist America. Education Reform and the Realities of Economic Life. London: Routledge and Kegan Paul.

Bray, M. (2003) 'Community Initiatives in Education: goals, dimensions and linkages with governments,' Compare 33(1): 31-45.

Bray, M. (2000) Community partnerships in education: Dimensions, variations and implications. Dakar: EFA Thematic Study. Available from:

< http://unesdoc.unesco.org/images/0012/001234/123483e.pdf> [Accessed 21 January 2006].

Bray, M. (nd) 'The nature and role of nonformal education: Some third world-first world lessons and contrasts.' Available from:

http://209.85.165.104/search?q=cache:yoQ4vCpA6WMJ:sunzi1.lib.hku.hk/hkjo/view/33/ 3300282.pdf+nonformal+education+bray\&hl=en\&ct=clnk\&cd=1 [Accessed 24 January 2007]

Bray, M. with K. Lillis (1988) Community Financing of Education. Issues and Policy Implications in Less Developed Countries. Oxford: Pergamon Press

Bruns, B., A. Mingat and R. Rakotomalala (2003) Achieving universal primary education by 2015: a chance for every child. Washington DC: World Bank.

Caillods, F. and J. Hallak (2004) Education and PRSPs: A Review of Experiences. Paris: UNESCO.

CAMPE (1999) Education Watch: Hope not Complacency. CAMPE: Dhaka.

CAMPE (2000) Education Watch: A Question of Quality. CAMPE: Dhaka.

CAMPE (2004) Directory of NGOs with Education Programme. Bangladesh Dhaka: CAMPE.

CARE, the George Washington University and Groundwork, (2002) Bangladesh Education Sector Review, Report No. 4: Teachers and Teacher Training (Formal and Nonformal) Available from: $<$ http://www.beps.net/publications/BANGLADESH\%204\%20TEACHERS\%20AND\%20TEACHER\%20TRAINING.pdf> [Accessed 18 January 2007]. 
Carron, G. and R. Carr-Hill (1991) Non-Formal Education: Information and Planning Issues IIEP, UNESCO: Paris.

Charlick, J. (2005) Accelerated learning for children in developing countries. Joining research and practice. Available from:

$<$ http://www.beps.net/publications/ACLFoldoutLETTER.pdf\#search=\%22charlick\%20no n-formal\%22> [Accessed 28 August 2006].

Chowdhury, A. F. and Rose, P. (2004) 'Non-state provision of basic services: Education in Bangladesh’ Mimeo. Birmingham: University of Birmingham.

Colclough, C. (1982) 'The impact of primary schooling on economic development: A review of the evidence,' World Development 10(3): 167-185.

Colclough, C., Al-Samarrai, S., Rose, P., Tembon, M. (2003) Achieving Schooling for All in Africa: Costs, Commitment and Gender. Ashgate Press, Aldershot.

Colenso, P. (2005) 'Achieving the education millennium development goals in fragile states what is the role of aid?' Unpublished Critical Analytical Study for the Professional Doctorate in Education, University of Sussex.

Coombs, P. and M. Ahmed (1974) Attacking Rural Poverty. How non-formal education can help. Baltimore: John Hopkins Press.

Consortium for Research on Educational Access, Transitions and Equity (CREATE) Available from: <http://www.create-rpc.org/about/conceptual_background.shtml $>$ [accessed 18 January 2007].

Cummings, C. et al (2004) 'Scoping study of potential mechanisms for strategic financing of NGO provision of health and education services.' Mimeo. Report for DFID. Cambridge Education Consultants.

DeStefano, J., A. Hartwell, J. Benbow, and A. Schuh Moore (2005) Cost-effectiveness of complementary approaches. USAID. Available from: < http://www.equip123.net/docs/e2MeetingEFA_WP.pdf $>$ [Accessed 28 August 2006].

DeStefano J, with A. Hartwell, D. Balwanz and A. Schuh Moore (2006) Effective schools for disadvantaged and underserved populations. Association for the Development of Education in Africa. Biennale Conference on Education in Africa. Available from: http://www.adeanet.org/biennial-2006/Ecoles/vo/Word/B5_1_destefano_en.doc [Accessed 24 January 2007].

DFID (2001) The Challenge of Universal Primary Education. Strategies for Achieving the International Development Targets. London: DFID.

DFID (2005) Girl's education: towards a better future for all. London: Department for International Development.

DFID and Her Majesty's Treasury (2006) Keeping our promises: Delivering education for all. (2006) Available from: <http://www.dfid.gov.uk/pubs/files/education-deliveringpromises.pdf $>$ [Accessed 18 January 2007].

Edwards, M., and D. Hulme. (eds.) (1995) Non-Governmental Organisations-Performance and Accountability: Beyond the Magic Bullet. London: Earthscan Publications.

Federal Democratic Republic of Ethiopia (2002) Education Sector Development Program II (ESDP-II) 2002/2003-2004/2005. Program Action Plan. Ministry of Education: Addis Ababa. 
Fine, B. and P. Rose (2001) Education and the post-Washington consensus, in B. Fine, C. Lapavitsas and J. Pincus (Eds.), Development Policy in the Twenty-first Century: Beyond the post-Washington consensus. London: Routledge.

Freire, P. (1972) Pedagogy of the Oppressed. London: Penguin.

FTI (2005) 'Exploring the desirability and feasibility of expanding the EFA Fast-Track Initiative to fragile states,' Background paper for the FTI Partnership, submitted by an inter-agency Task Team (DFID, USAID, Belgian Cooperation, World Bank, Global Campaign for Education, UNICEF, UNESCO, CIDA).

Government of Ghana (2003) 2003-2015 Education Strategic Plan. Accra: Government of Ghana.

Government of India (1976) $5^{\text {th }}$ Five Year Plan (1976-1980). Available from: $<$ http://planningcommission.nic.in/plans/planrel/fiveyr/welcome.html> [Accessed 18 January 2007].

Government of India (1980) $6^{\text {th }}$ Five Year Plan (1980-1984). Available from: $<$ http://planningcommission.nic.in/plans/planrel/fiveyr/welcome.html $>$ [Accessed 18 January 2007].

Government of India (1985) $7^{\text {th }}$ Five Year Plan (1985-1989). Available from: $<$ http://planningcommission.nic.in/plans/planrel/fiveyr/welcome.html $>$ [Accessed 18 January 2007].

Government of India (1992) $8^{\text {th }}$ Five Year Plan (1992-1996). Available from: $<$ http://planningcommission.nic.in/plans/planrel/fiveyr/welcome.html $>$ [Accessed 18 January 2007].

Government of India (1997) $9^{\text {th }}$ Five Year Plan (1997-2001). Available from:

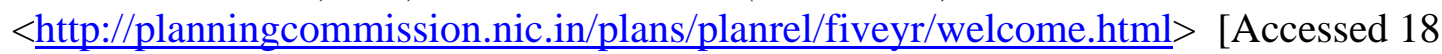
January 2007].

Government of India (2002) $10^{\text {th }}$ Five Year Plan (2002-2007). Available from: $<$ http://planningcommission.nic.in/plans/planrel/fiveyr/welcome.html $>$ [Accessed 18 January 2007].

Government of India, Ministry of Human Resource Development. (2002) Sarva Shiksha Abhiyan, A programme for Universalization of Elementary Education. Available from: <http://ssa.nic.in/altsch/egs.asp\#Background\%20: The\%20Current\%20NFE\%20Scheme> [Accessed 18 January 2007].

Government of People's Republic of Bangladesh (2005) Unlocking the Potential: National Strategy for Accelerated Poverty Reduction. Dhaka: Planning Commission, Government of People's Republic of Bangladesh.

Groundwork Inc. (2002) Bangladesh Education Sector Review No. 3. NGOs as Deliverers of Basic Education Paper prepared for Basic Education and Policy Support Activity, Washington DC: USAID. Available from: http://www.beps.net/publications/BANGLADESH\%203\%20NGOS\%20AS\%20DELIVERERS\%200F\%20BASIC\%20EDUCATION.pdf [accessed 18 January 2007]

Hannum, E. and C. Buchmann (2005) 'Global educational expansion and socio-economic development: An assessment of findings from the social sciences,' World Development, 33(3): 333-354. 
Harper, C., R. Marcus and K. Moore (2003) 'Enduring poverty and the conditions of childhood: lifecourse and intergenerational poverty transmissions,' World Development $31: 3(535-554)$.

Hartwell, A. (2004) 'Meeting EFA: Ghana School for Life' USAID EQUIP2 Case Study. Available from: http://www.aed.org/ToolsandPublications/upload/GhanaCaseStudy.pdf [Accessed 24 January 2006].

Hoppers, W. (2006) Non-formal education and basic education reform: a conceptual review. IIEP, UNESCO: Paris.

Hossain, N., R. Subrahmanian and N. Kabeer (2002) 'The Politics of Educational Expansion in Bangladesh’ IDS Working Paper 167. Brighton: Institute of Development Studies.

Hyde K.A.L., Kadzamira E.C. Sichinga J.N., Chibwana M.P. \& Ridker R.G. (1996) Village Based Schools in Mangochi: Evaluation Report. Zomba: Centre for Educational Research and Training, University of Malawi.

Ilon, L. (2002) Cost evaluation of complementary basic education programs in Uganda. Washington DC: Creative Associates Intl. Available from: http://www.beps.net/publications/COST\%20EVALUATION\%20OF\%20COMPLEMENT ARY\%20BASIC\%20EDUCATION\%20PROGRAMS.pdf [Accessed 24 January 2007].

JICA (2002) Approaches for systematic planning of development projects (Basic Education). Available from: <http://www.jica.go.jp/english/resources/publications/study/topical/spd/pdf/chapter1.pdf> [Accessed 18 January 2007].

Jones, P. (1988) International Policies for Third World Education: UNESCO, Literacy, and Development. New York: Routledge.

Kadzamira, E. and P. Rose (2004) 'Non state provision of basic services in Malawi: Education.' Mimeo. Birmingham: University of Birmingham. Available at: http://www.idd.bham.ac.uk/service-providers/stage2.htm [Accessed 24 January 2007].

King, K. and P. Rose (2005) 'International development targets and education: Towards a new international compact or a new conditionality?' Journal of International Development 17: 97-100.

Kirk, J. and R. Winthrop (nd) Home-Based Schools in Afghanistan, IRC, New York.

Lewin, K. (1995) Education and Development; The Issues and the Evidence. London: Overseas Development Administration.

Lewin, K. and Y. Sayed (2005) Non-Government Secondary Schooling in Sub-Saharan Africa: Exploring the Evidence in South Africa and Malawi. London: Department for International Development.

Malena, C. (2000) 'Beneficiaries, mercenaries, missionaries and revolutionaries: 'unpacking' NGO involvement in World Bank-financed projects,' IDS Bulletin 31(3).

Meagher, P. (2005) Service delivery in fragile states: framing the issues. IRIS Center: University of Maryland.

Melin, M. (ed.) (2001) Education - a Way out of Poverty? Available from: $<$ http://www.sida.se/shared/jsp/download.jsp?f=Edd12.pdf\&a=2792> $\quad$ [Accessed 18 January 2007]. 
Mfum-Mensah, O. (2003) 'Fostering educational participation in pastoral communities through non-formal education: the Ghanaian perspective,' International Journal of Educational Development 23(6): 661-677.

Miller-Grandvaux, Y., M. Welmond, and J. Wolf (2002) Evolving Partnerships: The Role of NGOs in Basic Education in Africa. United States Agency for International Development, Bureau of Africa, Office of Sustainable Development: Washington D.C.

Miwa, K. (2003) 'Government-NGO partnership and children's right to education in Bangladesh,' in N. Kabeer, G. Nambissan and R. Subrahmanian (eds) Child Labour and the Right to Education in South Asia: Needs versus Rights? Dhaka: The University Press Limited.

MOESS (2006) 2006 Education Sector Performance Report. Accra: MOESS.

Molteno, M., K. Ogadhoh, E. Cain and B. Crumpton (1999) 'Towards responsive schools: Supporting better schooling for disadvantaged children: Case studies from Save the Children,' DFID Knowledge and Research Papers No. 38. London: DFID.

Mundy, K. and L. Murphy (2001) 'Transnational advocacy, global civil society? Emerging evidence from the field of education,' Comparative Education Review 45(1): 85-126.

Nair, P. (2004) 'India: Desk study of non-state providers of basic services.' Mimeo. Birmingham: University of Birmingham. Available from: http://www.idd.bham.ac.uk/service-providers/stage2.htm [Accessed 24 January 2007].

ODI (1995) 'NGOs and official donors,' ODI Briefing Paper 4/1995.

Republic of Ghana (2005) Growth and Poverty Reduction Strategy, 2006-2009. Accra: National Development Planning Commission. Available from: http://siteresources.worldbank.org/INTPRS1/Resources/Ghana_PRSP(Nov-2005).pdf [Accessed 24 January 2007].

Rogers, A. (2004) 'Looking again at non-formal and informal education - towards a new paradigm', the encyclopaedia of informal education, Available from: $<$ www.infed.org/biblio/non_formal_paradigm.htm $>$ [Accessed 28 August 2006].

Rose, P. (2003a) 'Community participation in school policy in Malawi: Balancing local knowledge, local policies and international agency priorities,' Compare 33(1): 47-64.

Rose, P. (2003b) Out-of-school children in Ethiopia. Report for DFID-Ethiopia.

Rose, P. (2003c) 'From the Washington to the post-Washington consensus: The influence of international agenda on education policy and practice in Malawi,' Globalisation, Education and Societies 1(1): 67-86.

Rose, P. (2005) 2005 'Decentralisation and privatisation in Malawi - Default or design?' Compare 35(2).

Rose, P. (2007) 'Supporting non-state providers in basic education service delivery.' CREATE Discussion Paper No 4. Brighton: University of Sussex.

Rose, P. and C. Dyer (2006) Education and Chronic Poverty: A review of the literature. Paper for the Chronic Poverty Research Centre. London: ODI.

Rose, P. and M. Greeley (2006) 'Education and fragile states: Capturing lessons and identifying good practice.’ Paper prepared for OECD DAC Fragile States Group. 
Rose, P. and R. Subrahmanian (2005) 'Evaluation of DFID policies and practices on gender equality and women's empowerment,' DFID Evaluation Department Working Paper No 11.

Samoff, J. and E. M. Sebatane (2001) Scaling-up by focusing down: Creating space to expand education reform. Paris, Association for the Development of Education in Africa.

Sayed, Y. and C. Soudien (2003) '(Re)framing education exclusion and inclusion discourses: Limits and possibilities,’ IDS Bulletin 34(1): 9-17.

Thompson, E. (2001) Successful experiences in non-formal education and alternative approaches to basic education in Africa. ADEA. Available from:

$<$ http://www.adeanet.org/wgnfe/publications/biennial01/Thompson\%20Paper-

\%20final.pdf $>$ [Accessed 28 August 2006].

Torres, R. (2001) Amplifying and diversifying learning: Formal, non-formal and informal education revisited. ADEA.

Available from: <http://www.adeanet.org/wgnfe/publications/biennial01/RMTorres\%20\%20ADEA\%20Biennale\%20outline.pdf> [Accessed 28 August 2006].

UNESCO (2004) EFA Global Monitoring Report: Gender and Education: The Leap to Equality. UNESCO: Paris.

UNESCO (2005) EFA Global Monitoring Report: The Quality Imperative. UNESCO: Paris.

UNESCO (2006a) Global Monitoring Report: Literacy for Life Paris: UNESCO.

UNESCO (2006b) Synergies between formal and non-formal education. An overview of good practices. UNESCO: Paris.

UNESCO, Disadvantaged Groups - Alternative strategies of education and training for disadvantaged groups

Available from: <http://www.unesco.org/iiep/eng/research/comproj/disadvantaged.htm> [Accessed 18 January 2007].

UNESCO (2000), Education for All: Meeting our Collective Commitments Available from: $<$ http://www.unesco.org/education/efa/ed_for_all/dakfram_eng.shtml> [Accessed 18 January 2007].

UNESCO (1990) World Declaration on Education for All Available from:

<http://www.unesco.org/education/efa/ed_for_all/background/jomtien_declaration.shtml> [Accessed 18 January 2007].

World Bank (1999) Education Sector Strategy. Washington DC: World Bank.

World Bank. (2004) World Development Report 2004: Making Services Work for the Poor. The World Bank \& Oxford University Press: Washington. D.C.

World Bank. (2005) World Development Report 2005. The World Bank \& Oxford University Press: Washington. D.C. 


\section{reate}

\section{Consortium for Research on}

Educational Access, Transitions \& Equity

\section{Funded by DFID}

\section{Report summary:}

The paper focuses on approaches by non-government organisations (NGOs) to reaching primary school-aged children excluded from any access to the conventional state education system. It highlights recent shifts in the portrayal of NGO provision as an 'alternative' to state schooling, towards developing approaches for 'complementary' provision. A reason for this shift is to provide opportunities for 'mainstreaming' of graduates from NGO provision within the formal system, which is seen as a marker of progress towards achieving Education for All goals. The paper concludes that a move in this direction requires greater attention to developing a state-wide system of education which draws together multiple providers within a commonlyagreed framework.

\section{Author notes:}

Dr Pauline Rose is Reader in Education at the Centre for International Education, University of Sussex. Pauline's research relates to economics and governance of education in South Asia and sub-Saharan Africa. She has published extensively on the role of international agencies in shaping national policies and practices, with a particular focus on issues related to non-state provision of education. She is currently co-investigator on an ESRC-funded research project on non-government public action of basic services in Bangladesh, India and Pakistan, for which she is lead researcher on education.

Address for Correspondence:

CREATE, Centre for International Education

Sussex School of Education, University of Sussex

Brighton BN1 9QQ, UK.

Website: http://www.create-rpc.org

Email: create@sussex.ac.uk
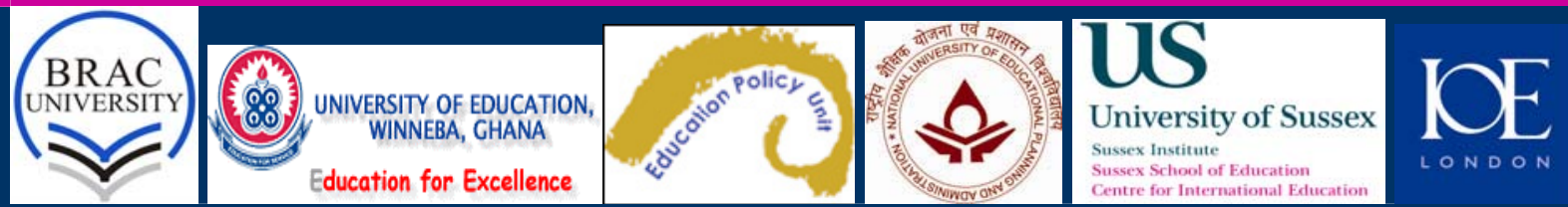